\title{
An-arrgh-chy: The Law and Economics of Pirate Organization
}

\author{
Peter T. Leeson
}

George Mason University

\begin{abstract}
This article investigates the internal governance institutions of violent criminal enterprise by examining the law, economics, and organization of pirates. To effectively organize their banditry, pirates required mechanisms to prevent internal predation, minimize crew conflict, and maximize piratical profit. Pirates devised two institutions for this purpose. First, I analyze the system of piratical checks and balances crews used to constrain captain predation. Second, I examine how pirates used democratic constitutions to minimize conflict and create piratical law and order. Pirate governance created sufficient order and cooperation to make pirates one of the most sophisticated and successful criminal organizations in history.
\end{abstract}

Nature, we see, teaches the most Illiterate the necessary Prudence for their Preservation . . . these Men whom we term, and not without Reason, the Scandal of human Nature, who were abandoned to all Vice, and lived by Rapine; when they judged it for their Interest . . . were strictly just . . among themselves. (Captain Charles Johnson 1726$28,527)$

I am especially grateful to Steven Levitt and two anonymous referees for thorough and insightful comments on an earlier draft of this paper. I also thank Pete Boettke, Tyler Cowen, Chris Coyne, Josh Hill, Bill Reece, Andrei Shleifer, Russell S. Sobel, Werner Troesken, and William Trumbull for helpful comments and suggestions. The financial support of the Kendrick Fund and the Kaplan Fund is also gratefully acknowledged.

[ Journal of Political Economy, 2007, vol. 115, no. 6]

(C) 2007 by The University of Chicago. All rights reserved. 0022-3808/2007/11506-0001\$10.00 


\section{Introduction}

Pirates are known for raucousness, recklessness, and chaotic rapine. Pirate reality, however, is quite another picture. Real-life pirates were highly organized criminals. Unlike the swashbuckling psychopaths of fiction, historical pirates displayed sophisticated organization and coordination.

Pirates could not use government to enforce or otherwise support cooperative arrangements between them. Despite this, they successfully cooperated with hundreds of other rogues. Amidst ubiquitous potential for conflict, they rarely fought, stole from, or deceived one another. In fact, piratical harmony was as common as harmony among their lawful contemporaries who relied on government for social cooperation. How did "these men whom we term . . . the Scandal of human Nature, who were abandoned to all Vice, and lived by Rapine" (Johnson [1726-28] $1999,527)^{1}$ accomplish this impressive level of order?

Becker (1968) was the first to apply the logic of rational-choice decision making to criminals. Following him, a number of others extended this logic to decision making in the context of organized outlaws. Fiorentini and Peltzman (1995) provide the best and most comprehensive collection of essays that consider the economics of criminal organization. In addition, a large literature discusses the economic impact of organized crime, activities of criminal organizations, optimal strategies for preventing organized crime, and reasons for its emergence (see also, e.g., Anderson 1979; Reuter 1983, 1987; Jennings 1984; Arlacchi 1986; Jankowski 1991; Dick 1995; Konrad and Skaperdas 1998; Garoupa 2000; Skaperdas 2001; Chang, Lu, and Chen 2005).

Unlike these topics, the internal governance institutions of violent criminal organizations have received relatively little attention. ${ }^{2}$ The difficulty of "getting inside" criminal organizations is largely responsible for this. Levitt and Venkatesh's important work on street gangs (Levitt and Venkatesh 2000; Venkatesh and Levitt 2000) is an exception to this rule, as are Gambetta's (1993) and Reuter's (1983) superb studies of the Mafia. However, Levitt and Venkatesh focus on the financial organization of gangs rather than on their governance structures. Gambetta's and Reuter's studies are primarily concerned with the Mafia's provision of protection to outsiders and the organization of the illegal markets it serves.

\footnotetext{
${ }^{1}$ All page references to Johnson refer to the 1999 reprint. Page references to other early sources also refer to reprint editions if available.

${ }^{2}$ Anderson (1979), Reuter (1983), and Gambetta (1993) are the closest exceptions in this regard. Their excellent work considers some internal governance aspects of the Mafia but tends to focus primarily on the Mafia's relationship to protection and other markets. Important research by Polo (1995) examines governance institutions of criminal organizations, but does so theoretically.
} 
This article investigates the internal governance institutions of violent criminal enterprise by examining the law, economics, and organization of pirates. ${ }^{3}$ These "most treacherous rogues" terrorized the Caribbean, Atlantic Ocean, and Indian Ocean during the seventeenth and eighteenth centuries. Pirates formed a loose confederation of maritime bandits outside the law of any government.

To effectively organize their banditry, pirates required mechanisms to prevent internal predation, minimize crew conflict, and maximize piratical profit. I argue that pirates devised two institutions for this purpose. First, I analyze the system of piratical checks and balances that crews used to constrain captain predation. Second, I examine how pirates used democratic constitutions to minimize conflict and create piratical law and order. Pirates adopted both of these institutions before seventeenth- and eighteenth-century governments.

Their governance institutions were self-enforcing by necessity. Appealing to the formal enforcement mechanisms of the state is not an option for criminal organizations, including pirates. Although the maritime nature of piratical expeditions makes certain aspects of their internal organization and governance specific to pirates, my analysis highlights important problems that any form of organized criminal enterprise faces, as well as the institutional solutions such organizations employ to overcome these problems.

The literature that addresses the economics of organized crime focuses on the criminal organization as a supplier of some service, usually protection, to other actors inside and outside the criminal world. Schelling (1971), for instance, who was among the first to conduct this research, identifies the provision of enforcement services to other agents and, in line with this function, a monopoly on coercion as the distinguishing features of organized crime.

While this definition is perhaps appropriate for the Mafia, it neglects equally important organized criminal activities that do not provide useful services to others and do not involve a monopoly on coercion. An army of thieves, for instance, that coordinates its activities, requires internal mechanisms of governance, and combines in a long-term arrangement for concerted plunder is as much a criminal organization as the Mafia.

Pirates were clearly organized criminals and yet were not primarily in the business of providing services to anyone other than their members. ${ }^{4}$ Nor did they have a monopoly on force. Because of this, unlike

\footnotetext{
${ }^{3}$ This article is also closely connected to the literature that examines the private emergence of law and governance institutions. See, e.g., Friedman (1979), Benson (1988, 1989, 1990), Anderson and McChesney (2002), Anderson and Hill (2004), Anderson, Benson, and Flanagan (2006), and Leeson (2007a, 2007b, forthcoming).

${ }^{4}$ However, pirates did trade with European colonists.
} 
most discussions of criminal organization, mine takes a broader view of organized crime. This view encompasses any long-term arrangement between multiple criminals that requires coordination and involves agreements that, owing to their illicit status, cannot be enforced by the state. ${ }^{5}$ The emphasis of my analysis therefore shifts from the organization of criminal markets (the focus of existing research on the economics of organized crime) to the internal predation problem that criminal organizations face and the institutions that emerge in response to it.

To examine these features for pirates, I draw on a series of historical documents that provide a firsthand glimpse into their organization. The first of these is Captain Charles Johnson's General History of the Pyrates (1726-28), which contains reports on a number of history's most infamous pirates related by a pirate contemporary. ${ }^{6}$ I also draw on Alexander Exquemelin's (1678) invaluable account of the seventeenthcentury buccaneers. Exquemelin was a surgeon who sailed with the buccaneers and provides a detailed, firsthand account of their raids, system of rules, and social organization. The buccaneer William Dampier (1697-1707) also published a journal relating to his maritime exploits, which I make use of as well.

Buccaneers differ from "pure" pirates in that they frequently plundered ships with government sanction. However, many other times they plundered without official permission, as full-blown pirates. These protopirates, many of whom turned to pure piracy when governments stopped issuing licenses for plunder, influenced and anticipated the organization of pure pirates in the late seventeenth and early eighteenth centuries. Buccaneer records are therefore important for understanding the institutions and organization of seventeenth- and eighteenth-century pirates.

In addition to these sources, correspondence from colonial governors relating to piracy and records from the trials of various pirates, such as testimony from individuals taken prisoner by pirate ships and the tes-

\footnotetext{
${ }^{5}$ My definition of a criminal organization is therefore similar to Polo's as "one that cannot rely on the external enforcement of the judicial institutions and whose behaviour and possibilities are not constrained by the law" $(1995,87)$.

6 "Captain Johnson" is a pen name used by the author of A General History of the Pyrates. His true identity remains unknown. In 1932, John R. Moore claimed that Johnson was in fact Daniel Defoe. In the late 1980s, however, this view was overturned (see Furbank and Owens 1988), and today many pirate historians do not believe that Defoe is the author of this important book (see, e.g., Rediker 2004; Cordingly 2006; Woodard 2007; for the opposing view, see Rogozinski 2000). Whatever Johnson's true identity, it is agreed that he "had extensive first-hand knowledge of piracy" (Konstam 2007, 12). While it is widely acknowledged that Johnson's work contains some errors and apocryphal accounts (such as the community of Libertalia), "Johnson is widely regarded as a highly reliable source for factual information" on pirates (Rediker 2004, 180) and remains a definitive source historians rely on in constructing their accounts of seventeenth- and eighteenth-century piracy. As eminent pirate historian David Cordingly puts it, this book "is the prime source for the lives of many pirates of what is often called the Golden Age of Piracy" (2006, xx).
} 
timony of pirates themselves, form an important part of the historical record this article relies on. ${ }^{7}$ Finally, a few pirate captives, such as William Snelgrave (1734), whose captors ultimately released them, published longer works describing their harrowing captivity by pirate crews. ${ }^{8} \mathrm{I}$ also draw on these accounts, which provide important firsthand records describing piratical governance and organization. ${ }^{9}$

\section{A "Nest of Rogues"}

Seventeenth- and eighteenth-century pirates occupied the waterways that formed major trading routes. ${ }^{10}$ These included the waters surrounding the Bahamas that stood between ships traveling from Central America to Spain; the waters connecting Europe and the North American seacoast; those between Cuba and Haiti, which separated ships traveling from Europe and the west coast of Africa to Jamaica; and the waters around Madagascar traveled by ships sailing to and from India (Cordingly 2006, 88). These areas encompass major portions of the Atlantic and Indian Oceans, Caribbean Sea, and Gulf of Mexico. The trade routes connecting the Caribbean, North America's Atlantic seacoast, and Madagascar consequently formed a loop called the "pirate round" that many pirates traveled in search of prey.

The "golden age" of piracy, when pirates were at their strongest, extended from 1690 to 1730 (Konstam 2002, 94). ${ }^{11}$ The years from 1716 to 1722 mark the height of the golden age. "This was at a Time that the Pyrates had obtained such an Acquisition of Strength, that they were in no Concern about preserving themselves from the Justice of Laws" (Johnson 1726-28, 87). The pirates of this era include many well-known

${ }^{7}$ Jameson (1923) has edited an excellent collection of such records. Unless otherwise noted, all depositions and examinations quoted here are contained in his collection.

${ }^{8}$ Importantly, drawing on the historical episode of pirates helps overcome the problem of "getting inside" criminal organizations, noted above. Records from individuals who had direct experiences with pirates, as well as those that shed light on piratical governance mechanisms from pirates themselves, allow me to view pirates' criminal organization "from the inside."

${ }^{9}$ Additionally, this article relies on and is greatly indebted to a voluminous modern literature covering all aspects of piracy, including those considered here, written by contemporary historians. Some of the best discussions belong to Gosse (1946), Pringle (1953), Rankin (1969), Rediker (1981, 1987), Cordingly (1996, 2006), Rogozinski (2000), and Konstam (2002).

${ }^{10}$ The "nest of rogues" terminology in this section's heading comes from Governor William Spotswood, who, in a letter to the British Lords of the Admiralty, complained of the growing pirate problem in New Providence (July 3, 1716 [1882, 2:168]).

${ }^{11}$ The dates given by historians to mark the golden age of piracy vary. Cordingly (2006) provides a slightly larger range, from about 1650 to 1725 . Still others, such as Rankin (1969), date the great age of piracy as encompassing the years between 1630 and 1720 . The further back in this range one goes, the more one is dealing with buccaneers as opposed to pure pirates. 
sea robbers, such as Blackbeard, whose real name was Edward Teach, Bartholomew Roberts, and others.

Pirates were a diverse lot. ${ }^{12}$ A sample of 700 pirates active in the Caribbean between 1715 and 1725, for example, reveals that 35 percent were English, 25 percent were American, 20 percent were West Indian, 10 percent were Scottish, 8 percent were Welsh, and 2 percent were Swedish, Dutch, French, and Spanish (Konstam 2002, 9). Others came from Portugal, Scandinavia, Greece, and East India (Marx 1996b, 103).

Pirate crews were also racially diverse. Based on data available from 23 pirate crews active between 1682 and 1726, the racial composition of ships varied between 13 and 98 percent black. If this sample is representative, 25-30 percent of the average pirate crew was of African descent (Kinkor 2001, 200-201).

The pirate population is difficult to precisely measure but by all accounts was considerable. ${ }^{13}$ According to the reports of contemporaries and estimates of pirate historians, in any one year between 1716 and 1722 the loop that formed the pirate round contained between 1,000 and 2,000 sea bandits (see, e.g., Johnson 1726-28, 132; Pringle 1953, 185; Rediker 1987, 256; Marx 1996b, 102, 111; Konstam 2002, 6). ${ }^{14}$ The buccaneering community of the seventeenth century must have been even larger than this since, as I discuss below, some firsthand observers report single expeditions of 2,000 men (Exquemelin [1678] 2000, 171).

Contrary to most people's images of pirate crews, they were quite large. On the basis of figures from 37 pirate ships between 1716 and 1726, it appears that the average crew had about 80 members (Rediker 1987, 256; see also Deposition of Simon Calderon 1682, Public Record Office, Colonial Office Papers 1:50, no. 139). A number of

\footnotetext{
${ }^{12}$ Pirates also exhibited some diversity in social standing. Although most pirates were uneducated and came from the lower classes of society, a few, such as Dr. John Hincher, were well educated and came from higher stations in life (Cordingly 2006).

${ }^{13}$ Pure pirates should be distinguished from buccaneers, privateers, and corsairs. Pure pirates were total outlaws and attacked merchant ships indiscriminately for their own gain. Privateers and corsairs, in contrast, were both state-sanctioned sea robbers. Governments licensed the former to attack enemy ships in times of war. Governments licensed the latter to attack the ships of other nations on the basis of religion. "Buccaneering was a peculiar blend of piracy and privateering in which the two elements were often indistinguishable" (Marx 1996a, 38). Oftentimes, buccaneers plundered with official sanction, making them more like privateers than pirates. Many other times, however, they did not. In these cases they were acting as pure pirates.

${ }^{14}$ These numbers are especially large when one puts them in historical perspective. The Royal Navy, e.g., averaged only 13,000 men in any one year between 1716 and 1726, making the pirate population in a good year more than 15 percent of the navy population (Rediker 1987, 256). In 1680, the total population of the American colonies was less than 152,000 (Hughes and Cain 1994, 20). In fact, as late as 1790, when the first U.S. census was taken, only 24 places in the country had populations greater than 2,500 (Hughes and Cain 1994, 28).
} 
pirate crews were closer to 120, and crews of 150-200 were not uncommon (see, e.g., Snelgrave [1734] 1971, 199; Examination of John Brown, May 6, 1717, Suffolk Court Files, no. 11945, paper 5; Deposition of Theophilus Turner, June 8, 1699, Public Record Office, Colonial Office Papers 5:714, no. 70 VI; Examination of John Dann, August 3, 1696, London, Public Record Office, Colonial Office Papers 323:2, no. 25; Deposition of Adam Baldridge, May 5, 1699, Public Record Office, Colonial Office Papers 5:1042, no. 30 II; Johnson 1726-28, 442; Cordingly 2006, 165).

Several pirate crews were bigger than this. For example, Blackbeard's crew aboard the Queen Anne's Revenge was 300 men strong (Public Record Office, Colonial Office Papers 152/12, no. 67, iii; quoted in Cordingly 2006, 165-66; see also Marx 1996b, 112). Even a sixth-rate Royal Navy ship in the early eighteenth century carried more crew members than the average pirate vessel (about 150). But compared to the average 200ton merchant ship, which carried only 13-17 men, pirate ships were extremely large (Rediker 1987, 107). Furthermore, some pirate crews were too large to fit in one ship. In this case they formed pirate squadrons. Captain Bartholomew Roberts, for example, commanded a squadron of four ships that carried 508 men (Cordingly 2006, 111).

In addition to this, multiple pirate ships sometimes joined for concerted plundering expeditions. The most impressive fleets of sea bandits belong to the buccaneers. Alexander Exquemelin, for example, records that Captain Morgan commanded a fleet of 37 ships and 2,000 men sufficient to attack coastal communities on the Spanish Main (1678, 171). Elsewhere, he refers to a group of buccaneers who "had a force of at least twenty vessels in quest of plunder" (69; see also 85, 105, 93). Similarly, William Dampier ([1697-1707] 2005, 62) records a pirating expedition that boasted 10 ships and 960 men. ${ }^{15}$ Though their fleets were not as massive, eighteenth-century pirates also "cheerfully joined their Brethren in Iniquity" to engage in multicrew pirating expeditions (Snelgrave 1734, 198).

\section{Merchant Ship Organization}

\section{A. Efficient Autocracy}

Although some pirates came from the Royal Navy, most sailors who entered piracy came from the merchant marine. Merchant ships were

\footnotetext{
${ }^{15}$ In the South China Sea, Cheng I commanded a pirate confederacy that boasted an astonishing 150,000 members (Konstam 2002, 174). Chinese pirates sometimes sailed together in fleets of several hundred ships.
} 
organized hierarchically. ${ }^{16}$ On top was the captain, below him were his officers, and far below these were ordinary seamen. This hierarchy empowered captains with autocratic authority over their crews. The captain's authority gave him control over all aspects of life aboard his ship, including provision of victuals, wage payment, labor assignment, and, of course, crew member discipline.

Merchant ship autocracy reflected an efficient institutional response to the specific economic situation these ships confronted and, in particular, the ownership structure of merchant vessels. Merchant ships were owned by groups of typically a dozen or more landed merchants who purchased shares in various trading vessels and financed their voyages. ${ }^{17}$ In addition to supplying the capital required for ships' construction and continued maintenance, owners outfitted their vessels, supplied them with provisions, advanced sailor wages, and, most important, solicited customers (who were other landed merchants) and negotiated terms of delivery and freight.

Merchant ship owners were absentee owners of their vessels; they did not sail on their ships. ${ }^{18}$ They were landlubbers. Most merchant ship owners did not desire to take their chances with brutal life at sea, and in any event could earn more by specializing in their area of expertiseinvestment and commercial organization-hiring seamen to sail their ships instead. ${ }^{19}$

Because they were absentee owners, merchant ship owners confronted a principal-agent problem with respect to the crews they hired. Once a ship left port it could be gone for months. ${ }^{20}$ At sea, the owners' ship was beyond their watchful eyes or reach. Thus, ship owners could not directly monitor their sailors.

This situation invited various kinds of sailor opportunism. Opportun-

${ }^{16}$ Navy ships were also organized hierarchically. Their captains were commissioned by the Admiralty (typically on the recommendation of superior commissioned officers) and had command over crew activities, power to physically punish sailors (or to direct/authorize lower-ranking officers to do so), etc. Captains of larger naval ships did not, however, have control over victuals, which were instead controlled by a warrant officer called the "purser." The purser's logs, which documented victuals distributed, were often approved by the captain.

${ }^{17}$ Ownership groups were sizable because of the need to diversify the risk of merchant shipping. Each merchant purchased a small share in many ships rather than being the sole owner of one.

${ }^{18}$ Because most merchant ships were owned by groups of investors, even in cases in which a merchant captained his vessel himself, there remained absentee owners, his coinvestors.

${ }^{19}$ Absentee ownership was further assured by the fact that the members of merchant vessel ownership groups engaged in many more commercial activities besides their concern in a particular merchant ship. These other commercial activities often required merchants to be on land to tend to their affairs rather than at sea.

${ }^{20}$ Although merchant ships engaged in coastal trade were at sea for shorter periods, merchant ships engaged in long-distance trade could be gone for periods of nine months or more. 
ism included negligence in caring for the ship, carelessness that damaged cargo, liberality with provisions, embezzlement of freight or advances required to finance the vessel's voyage, and outright theft of the vessel itself.

To prevent this, ship owners appointed captains to their vessels to monitor crews in their stead. Centralizing power in a captain's hands to direct sailors' tasks, control the distribution of victuals and payment, and discipline and punish crew members allowed merchant ship owners to minimize sailor opportunism. As noted above, merchant ships tended to be quite small. Consequently, captains could cheaply monitor sailors' behavior to prevent activities (or inactivities) that were costly to ship owners and secure sailors' full effort. ${ }^{21}$

Admiralty law facilitated captains' ability to do this by granting them authority to control their crews' behavior through corporal punishment. The law empowered captains to beat crew members with the infamous (and ominous) cat-o-nine-tails, imprison them, and administer other forms of harsh physical "correction" to sailors who disobeyed orders, shirked in their duties, and so forth. It also permitted captains to dock sailors' wages for damaging or stealing cargo and insubordination.

To align owner-captain interests, owners used two devices. First, they hired captains who held small shares in the vessels they were commanding or, barring this, gave small shares to their captains who did not. Merchant ship captains continued to draw regular fixed wages like the other sailors on their vessels. ${ }^{22}$ But unlike regular sailors, captains became partial residual claimants of the ships they controlled, aligning their interests with those of the absentee owners. ${ }^{23}$ Second, whenever

\footnotetext{
${ }^{21}$ In addition to using autocratic captains to cope with this principal-agent problem, merchant ships also held back a portion (or sometimes all) of sailors' wages until a voyage was complete.

${ }^{22} \mathrm{~A}$ few merchant ships engaged in part-time fishing used a share system of payment similar to the one privateers, whalers, and pirates used. However, the overwhelming majority of merchant ships used a fixed wage system. In vessels engaged in coastal shipping, sailors were paid lump-sum wages. In vessels engaged in long-distance shipping, sailors were paid monthly wages.

${ }^{23}$ The owner-sailor principal-agent problem could not have been overcome by converting every crew member's fixed wage to a profit-sharing scheme. Even under profit sharing, sailors would still have an incentive to consume cargo, liberal provisions, etc., and then blame the loss on the uncertainties of the sea, such as pirates or wrecks. Although this opportunism would reduce each sailor's share of the voyage's net proceeds, since the cost of such behavior is borne partially by the absentee owners, sailors have an incentive to act opportunistically. Further, converting sailor wages to shares would not have deterred the crew from the most costly kind of opportunism-absconding with the ship and its freight. Because the benefit of such theft would exceed the crew's fraction of a successful voyage's proceeds, which are shared with the absentee owners under a profit-sharing scheme, without an authority to monitor and control their behavior, crews would still have an incentive to steal the ships they sailed on. This is why both privateers and whaling ships, e.g., which used a pirate-like profit-sharing system but also had absentee owners, still required and used autocratic captains. On the efficiency of the fixed wage system for
} 
possible, absentee owners appointed captains with familial connections to one of the members of their group (Davis 1962, 128). This ensured that captains did not behave opportunistically at the absentee owners' expense since, if they did, they were more likely to face punishment. ${ }^{24}$

The reason merchant ship owners required autocratic captains to effectively serve their interests is straightforward. A captain who did not have total authority over his crew could not successfully monitor and control sailors' behavior. Reducing the captain's power over victuals, payments, labor assignment, or discipline, and vesting it in some other sailor's hands instead, would have concomitantly reduced the captain's power to make sailors behave in the absentee owners' interest.

Similarly, if merchant ship owners did not appoint their captains as the permanent commanders of their voyages, but instead permitted a ship's sailors to popularly depose the captain and elect another member of the crew to this office at their will, the captain's capacity as acting manager of the ship's absentee owners would cease to exist. To see this, simply imagine what kind of captain merchant sailors would elect if given the power to democratically select him. Sailors' interests were best served by a lax, liberal captain who let them do as they pleased-exactly the opposite sort of captain that best served the owners' interests. Merchant ship autocracy was therefore essential to overcoming the ownercrew principal-agent problem and thus to merchant ship profitability.

Merchant ship autocracy worked quite well in this respect. Although some sailors still managed to steal from the ships they sailed on, disobey command, and, as I discuss below, in several cases mutiny and abscond with the owners' ship, these were relatively unimportant exceptions to the general rule whereby merchant sailors, under the authority of autocratic captains, served their absentee owners' interests.

\section{B. The Problem of Captain Predation}

Although merchant ship autocracy largely overcame the principal-agent problem that absentee owners confronted with respect to their crews, in doing so it created potential for a different kind of problem: captain predation. The trouble was that a captain endowed with the authority required to manage his crew on the ship owners' behalf could also easily turn this authority against his seamen for personal benefit. As British

the merchant marine and efficiency of the share system for privateers and whalers, which also applies to pirates, see Gifford (1993).

${ }^{24} \mathrm{~A}$ third device owners used for this purpose, though of declining importance over time, was that of the supercargo-an agent hired by the ship's owners who sailed on the ship and managed commercial aspects of the voyage, such as buying and selling cargo at port, and sometimes deciding what ports the ship should stop at, when the captain could not be trusted in these capacities (Davis 1962). 
marine commander William Betagh characterized the problem, "unlimited power, bad views, ill nature and ill principles all concurring" "in a ship's commander," "he is past all restraint" $(1728,41)$.

Betagh's opinion of some captains' "ill nature" notwithstanding, merchant captains were not necessarily bad men. But they were rational economic actors and thus responded to the incentives their institutional environment created. Endowed with autocratic authority over their crews, some merchant captains used the power their employers and Admiralty law gave them to prey on their sailors. As a result of merchant ships' autocratic organization, captains "had absolute authority over the mates, the carpenters and boatswain, and the seamen." They had the power to "make life tolerable or unbearable as they wished" (Davis 1962, 131-32). Unfortunately for seamen, more than a few captains opted for the latter.

As Marcus Rediker points out, according to several pirates, merchant captain mistreatment of ordinary seamen was largely responsible for driving sailors from this profession into the arms of sea bandits. The pirate John Archer's last words before being put to death testify to this. As he lamented, "I could wish that Masters of Vessels would not use their Men with so much Severity, as many of them do, which exposes us to great Temptations" (Johnson 1726-28, 351). In 1726 the pirate William Fly pleaded similarly while awaiting his death sentence: "Our Captain and his Mate used us Barbarously. We poor Men can't have Justice done us. There is nothing said to our Commanders, let them never so much abuse us, and use us like Dogs" (quoted in Rediker 1981, 218).

Captain predation took a number of forms, each the result of abusing the autocratic power captains had at their disposal. Predatory captains cut sailors' victual rations to keep costs down or to leave more for them and their fellow officers to consume. As one sailor testified, for example, although the members of his crew "were att short allowance and wanted bread," the officers "were allowed . . . their full allowance of provisions and liquors as if there had been no want of scarcity of any thing on board" (Babb v. Chalkley 1701, High Court of Admiralty Papers, 24/127; quoted in Rediker 1987, 247). Predatory captains also fraudulently docked sailors' wages or paid sailors in debased colonial currency (Morris 1965, 237; Rediker 1987). They might also voyage to a location where the crew had not contracted to sail (Gifford 1993, 144).

To keep their hungry and uncomfortable men in check, abusive captains could and did use all manner of objects aboard their ships as weapons to punish insolent crew members. They hit sailors in the head with tackle or other hard objects on board, crushing their faces, and used other barbaric tactics to discipline seamen (Jones v. Newcomin 1735, High Court of Admiralty Papers, 24/138; quoted in Rediker 1987, 216). 
As merchant ship captain Nathaniel Uring described how he dealt with a "seditious Fellow" on his ship, for instance, "I gave him two or three such Strokes with a Stick I had prepared for that purpose . . . the Blood running about his Ears, he pray'd for God's sake that I not kill him" ([1726] 1928, 176-77).

Besides preventing dissension, captains also used their kingly power to settle personal scores with crew members. Admiralty law considered interfering with captain punishment mutinous and thus prohibited crew members from doing so (Morris 1965, 264-65). Since captains effectively defined when punishment was legitimate, they were free to abuse seamen at will. As one seaman warned a newcomer, "There is no justice or injustice on board ship, my lad. There are only two things: duty and mutiny-mind that. All that you are ordered to do is duty. All that you refuse to do is mutiny" (quoted in Rediker 1987, 211). ${ }^{25}$

While the historical record contains plenty of charges of captain predation, it is important to avoid overstating the extent of this abuse. ${ }^{26}$ Although merchant captains had ample latitude to prey on their crews, this was not without limit. Several factors, economic and legal, constrained captain predation to some extent. ${ }^{27}$

But none was able to prevent it entirely. English law, for example, created several legal protections that were supposed to insulate sailors from captain predation. To a certain extent these protections were successful. Merchant seamen could and did take predatory captains to court for their actions, many times successfully.

However, as is often the case with the law, many other times it failed. Part of the difficulty here stemmed from the well-known uncertainties of the sea and the fact that, once they were afloat in the briny deep, there were rarely impartial spectators to be had to verify a sailor's word against a captain's. Did a captain dock a sailor's pay because the sailor damaged freight, as he was entitled to under the law? Or was the captain simply self-dealing? Had a captain exceeded the powers of corporal

\footnotetext{
${ }^{25}$ This quotation is from a late eighteenth-century sailor but captures the situation in the earlier part of the century as well.

${ }^{26}$ It is also important to note that captain predation notwithstanding, a merchant sailor's life was not a singularly cruel and oppressed one. As Earle (1998) points out, e.g., sailor society on merchant ships was in many ways a microcosm of landed life in seventeenthand eighteenth-century England. Rodger $(1996,2006)$ makes a similar point regarding life aboard naval vessels. My discussion here is not intended to suggest that life was exclusively or exceptionally poor aboard merchant (or navy) ships. My argument is only to point out that the necessarily autocratic organization of merchant ships created scope for merchant captain predation, which a number of captains seized on.

${ }^{27} \mathrm{~A}$ check on the extent of captain predation not discussed here was captains' ability to complete their voyages. If a predatory captain, for instance, maimed or otherwise severely injured too many crew members through overzealous discipline, he might not have enough healthy crew members to complete the voyage. This surely constrained captain abuse to some extent, though it did not provide an incentive to reduce abuse to zero nor to refrain from other kinds of predatory behavior discussed above.
} 
punishment afforded him under the law? Or was his discipline justified? In many cases it was difficult to say.

Further, the law itself regarding these matters could be unclear. Some sailors successfully sued their captains for merely pinching provisions. In other cases far more abusive captain conduct was supported by the law. In one case, for example, a captain beat his sailor with a one-anda-half inch rope for cursing. The court found he "had Lawful provocation to Correct the Complainant and had not Exceeded the bounds of Humanity" and dismissed the sailor's claim (Broughton v. Atkins, Massachusetts Vice-Admiralty Records, box II, fol. 25, 1727; quoted in Morris 1965, 264).

Reputation could also be effective in constraining captain predation. Although the sailor population in the mid-eighteenth century approached 80,000 (Gifford 1993, 147), there were fewer than 10,000 captains. The relatively small population of captains facilitated information sharing about captain behavior. Since merchant ships had to voluntarily attract sailors, this helped to dampen the predatory inclinations of some merchant captains.

Nevertheless, some captain-sailor relations were anonymous and nonrepeated. For example, when in 1722 merchant ship captains Isham Randolph, Constantine Cane, and William Halladay petitioned the colonial governor of Virginia for greater authority to discipline their sailors (who they complained were insolent for want of "fear of correction"), they wrote that "it is frequently the misfortune of Masters of Ships at their fitting out in England, to be obliged to ship men for forreign Voyages of whose disposition and character they have no knowledge" (quoted in Morris 1965, 271). Their letter suggests that the market for merchant sailors was, at least in some cases, largely anonymous. This implies not only that captains did not know the identity of sailors they employed, but also that sailors in some cases did not know the captains who employed them.

A number of sailors were the "fair weather" sort, drifting between employment at land and at sea, as job and pay prospects permitted. Others went to sea in between their regular work and thus had only sporadic interaction with a few members of the maritime community separated by lengthy periods. These features of the merchant sailor labor market made information sharing more difficult and rendered reputation a less effective constraint on captain abuse.

In assessing reputation's ability to check merchant captains' predatory inclinations, it is also important to remember that seventeenth- and eighteenth-century merchant shipping took place in the context of European mercantilism. Although some of England's mercantilist policies, such as bounties for shipbuilding, contributed to competition between merchant ships, others, such as the colonial law that forbade merchant 
ship captains from hiring away sailors who had already agreed to sail for another captain and the law that restricted foreign merchant captains from competing with English ones, retarded merchant ship competition and thus reputation's ability to check captain predation.

Another potential check on captain predation was the threat of mutiny. However, like other forms of revolution, mutiny was a risky and costly method of checking an authority's abuse. Crew members faced a collective action problem that often prevented them from overthrowing predatory captains.

Even on a merchant ship where every crew member agreed that the captain should be removed, sailors confronted the standard collective action problems of small-scale revolution. If crew members could coordinate their hatred and jointly revolt against a captain, in many cases they might have succeeded. However, since merchant ship crews were quite small, it was important to have all the sailors, or at least a significant majority, willing to fight. A successful mutiny might require not only the commitment of the common seamen but the commitment of the captain's officers as well. Acquiring certainty on the part of each sailor that if he rebelled against his captain, his fellow sailors would as well, was problematic. If one or several crew members "chickened out" at the last minute, the revolting sailor(s) might be defeated and, worse yet, face captain retribution.

Captain retribution involved using any of the powers at the captain's disposal to punish the mutineers. This ranged from imprisonment to extreme corporal punishment, further cutting the mutineers' rations or pay, or assigning them the most dangerous tasks on the ship (see, e.g., Uring 1726). Unless each sailor was assured that his fellow seamen had the courage and wherewithal to follow through on revolt, he was unwilling to rebel against his predatory captain.

This is not to say that merchant sailors never mutinied. Indeed, they did, but quite rarely. In the half century between 1700 and 1750, there were fewer than 60 documented mutinies on English and American merchant ships, about 1.18 per year (Rediker 1987, 227-28). It is possible that many more mutinies went undocumented. But even if we quadruple this number, which seems quite unreasonable, the number of merchant ship mutinies is tiny compared to the number of merchant ship voyages over this period. Further, this includes all attempted mutinies, not only the successful ones, which were even more rare. According to Rediker, only half of those documented between 1700 and 1750 were successful (228).$^{28}$ Thus, it appears that the collective action

${ }^{28}$ Notably, however, several pirate crews had their genesis in successful mutiny. According to Rediker (1987, 228), one-third of successful mutinous crews (i.e., those that succeeded in taking control of the ship) in the first half of the eighteenth century entered piracy. 
problem mutiny posed for merchant sailors was quite severe. Maritime revolution, then, was not a reliable method of reining in predatory merchant ship captains.

Why didn't those on the receiving end of captain predation-the common seamen-simply pool their resources, purchase their own merchant ship, and sail it themselves? Several factors appear to have prevented this possibility. Although a merchant ship officer might, after several years, save enough to purchase a small share in a merchant vessel, "Only if a seaman could raise the money to buy, not a tiny fraction but a substantial share-a half or more-would such a financial gesture by itself be sufficient to attract co-owners" (Davis 1962, 127).

Merchant shipping was not as simple as carrying goods from point A to point B. It crucially depended on connections with landed merchants, both at home and abroad, who were willing to take the risk of doing business with a particular group of ship owners, trade with these owners on credit, and so on. Landed merchants had established reputations along these lines, making it possible for them to secure investors and customers.

Salty sea folk, in contrast, did not. The common seventeenth- or eighteenth-century seaman occupied one of the lowest stations in the economic foodchain. He was "from the lowest ranks of society . . . from young men who were dissatisfied with, or could obtain no employment in, the lowest of shore occupations" (Davis 1962, 114). He had neither business experience nor connections. Needless to say, merchants were not lining up to put their valuable cargo under the care of sailor-owned and operated ships.

Even if several seamen had sufficient faith in one another's abilities to make a go of the seafaring portion of merchant shipping and, furthermore, were willing to risk dumping several years' savings into buying a ship owned together with other sailors, they would have had no reason to think that any of their co-owners commanded the business knowledge or connections required to make such a venture profitable. Nor would they have been able to attract the capital required to withstand even one unsuccessful voyage that resulted from shipwreck, pirate attack, or any of the other uncertainties of merchant shipping. ${ }^{29}$ Just as specialization required merchants to devote their time to organizing the commercial aspects of merchant voyages, leaving the sailing to the sailors, so too did specialization require seamen to focus on the sailing aspects

${ }^{29}$ In addition to this, there is considerable doubt that many common seamen, even after years of toil, were in a position to own any part of a merchant vessel. One of the few, preserved, near-complete bills of merchant vessel sale before England required ship registration in 1786 corroborates this. Among the 338 owners of 53 ships it lists, only 28 noncaptain mariners, or about 8 percent of the total, owned any share of a merchant vessel (Davis 1962, 100). 
of merchant voyages, leaving the commercial organization to the merchants.

\section{Pirate Ship Organization}

Like merchant ship organization, the particular economic situation pirate ships confronted crucially shaped their organization. Most notably, pirates did not confront the owner-crew principal-agent problem that merchant ships did. The reason for this is simple enough: pirates did not acquire their ships legitimately. They stole them. ${ }^{30}$

Pirate ships therefore had no absentee owners. On a pirate ship, the principals were the agents. As one historian described it, in this sense a pirate ship was like a "sea-going stock company" (Pringle 1953, 106). As a result, pirates did not require captains to align the crew's interests with those of the ship's absentee owners. This feature of piracy largely explains the stark contrast between merchant and pirate ship organization.

However, the absence of the owner-crew principal-agent problem on pirate ships does not mean that pirates did not need captains. They certainly did. Many important piratical decisions, such as how to engage a potential target, how to pursue when "chasing" a target or being chased by authorities, and how to react if attacked, required snap decision making. There was no time for disagreement or debate in such cases, and conflicting voices would have made it impossible to undertake the most essential tasks. Furthermore, pirate ships, like all ships, needed some method of maintaining order, distributing victuals and payments, and administering discipline to unruly crew members.

The office of captain overcame such difficulties by vesting autocratic control over these matters in the hands of an authority. In this sense, although pirate ships differed from merchant ships in requiring captains to solve an owner-sailor principal-agent problem, pirate ships were similar to merchant ships in requiring some kind of authority for their undertaking's success. Although a pirate ship's activity-violent plunder-was wholly different from a merchant ship's, both kinds of vessels shared the need to create internal order to achieve their ends.

The need for captains posed a dilemma for pirates. On the one hand, a captain who wielded unquestioned authority in certain decisions was critical for success. On the other hand, what was to prevent a captain with this power from behaving toward his pirate crew in the same manner that predatory merchant ship captains behaved toward their crews?

Since pirates did not have absentee owners but instead jointly owned

\footnotetext{
${ }^{30}$ There is at least one eighteenth-century pirate, however, Stede Bonnet, who actually purchased the first ship he went on the account with.
} 
the stolen ships they sailed on, although they required captains, unlike merchant ships, they did not require autocratic captains. Thus, in sharp contrast to the situation on merchant ships, pirates could and did democratically elect their captains without problem. Since the pirates sailing a particular ship were both the principals and the agents, democracy did not threaten to lead to captains who served the agents at the principals' expense. On the contrary, pirate democracy ensured that pirates got precisely the kind of captain they desired. Because pirates could popularly depose any captain who did not suit them and elect another in his place, pirate captains' ability to prey on crew members was greatly constrained compared to that of merchant ship captains.

Similarly, because pirates were both principals and agents of their ships, they could divide authority on their vessels to further check captains' ability to abuse crew members without loss. Unlike merchant ships, which could not afford a separation of power since this would have diminished the ability of the absentee owners' acting agent (the captain) to make the crew act in the owners' interests, pirate ships could and did adopt a system of democratic checks and balances.

\section{A. Piratical Checks and Balances}

Because of the threat of captain predation, pirates "were adamant in wanting to limit the captain's power to abuse and cheat them" (Rogozinski 2000, 174). To do this they instituted a democratic system of divided power, or piratical checks and balances, aboard their ships. As the pirate Walter Kennedy testified at his trial, "Most of them having suffered formerly from the ill-treatment of Officers, provided thus carefully against any such Evil now they had the choice in themselves . . . for the due Execution thereof they constituted other Officers besides the Captain; so very industrious were they to avoid putting too much Power into the hands of one Man" (Hayward [1735] 1874, 1:42).

The primary "other officer" pirates "constituted" for this purpose was the quartermaster. The way this office worked is straightforward. Captains retained absolute authority in times of battle, enabling pirates to realize the benefits of autocratic control required for success in conflict. However, pirate crews transferred power to allocate provisions, select and distribute loot (there was rarely room aboard pirate ships to take all they seized from a prize), and adjudicate crew member conflicts/ administer discipline to the quartermaster, whom they democratically elected:

For the Punishment of small Offences . . there is a principal Officer among the Pyrates, called the Quarter-Master, of the Men's own choosing, who claims all Authority this Way, (ex- 
cepting in Time of Battle:) If they disobey his Command, are quarrelsome and mutinous with one another, misuse Prisoners, plunder beyond his Order, and in particular, if they be negligent of their Arms, which he musters at Discretion, he punishes at his own dare without incurring the Lash from all the Ship's Company: In short, this Officer is Trustee for the whole, is the first on board any Prize, separating for the Company's Use, what he pleases, and returning what he thinks fit to the Owners, excepting Gold and Silver, which they have voted not returnable. (Johnson 1726-28, 213).

William Snelgrave, who observed the pirates' system of checks and balances firsthand, characterized the relationship between captain and quartermaster similarly: "the Captain of a Pirate Ship, is chiefly chosen to fight the Vessels they may meet with. Besides him, they chuse another principle Officer, whom they call Quarter-master, who has the general Inspection of all Affairs, and often controuls the Captain's Orders" (1734, 199-200). This separation of power removed captains' control over activities they traditionally used to prey on crew members, while empowering them sufficiently to direct plundering expeditions.

The institutional separation of powers aboard pirate ships predated its adoption by seventeenth- and eighteenth-century governments. France, for example, did not experience such a separation until 1789. Nor did the United States. The first specter of separated powers in Spain did not appear until 1812. In contrast, pirates had divided, democratic "government" aboard their ships at least a century before this. Arguably, piratical checks and balances predated even England's adoption of similar institutions. England did not experience a separation of powers until the Glorious Revolution of 1688 . However, the buccaneers, who used a similar, if not as thoroughgoing, system of democratically divided power as their pure pirate successors, had in place at least partial democratic checks and balances in the early 1680s (Rogozinski 2000).

Piratical checks and balances proved quite successful. According to Johnson, owing to the institution of the quartermaster, aboard pirate ships "the Captain can undertake nothing which the Quarter-Master does not approve. We may say, the Quarter-Master is an humble Imitation of the Roman Tribune of the People; he speaks for, and looks after the Interest of the Crew" (1726-28, 423). As noted previously, the only exception to this was "in Chase, or in Battle" when crews desired autocratic authority and thus, "by their own Laws," "the Captain's Power is uncontroulable" $(139,214) .{ }^{31}$

\footnotetext{
${ }^{31}$ Of course, even pirates' democratic system of checks and balances could not prevent all instances of captain predation. For instance, since he controlled battle-related decisions, a pirate captain could still put a crew member he disliked in harm's way.
} 
In addition to this separation of powers, pirates imposed a further check to balance captains' authority. They converted the office to a democratically elected one, "the Rank of Captain being obtained by the Suffrage of the Majority" (Johnson 1726-28, 214). The combination of separated powers and democratic elections for captains ensured that pirates "only permit him to be Captain, on Condition, that they may be Captain over him" (213).

Crews could vote captains out of office for any number of reasons. Predation was one, but so was cowardice, poor judgment, and any other behavior a crew did not feel was in its best interest. In this way pirates could be sure that captainship "falls on one superior for Knowledge and Boldness, Pistol Proof, (as they call it)" (Johnson 1726-28, 214).

The historical record contains numerous examples of pirate crews deposing unwanted captains by majority vote or otherwise removing them from power through popular consensus. Captain Charles Vane's pirate crew, for example, popularly deposed him for cowardice: "the Captain's Behavior was obliged to stand the Test of a Vote, and a Resolution passed against his Honour and Dignity . . . deposing him from the Command" (Johnson 1726-28, 139). Similarly, Captain Christopher Moody's pirate crew grew dissatisfied with his behavior and "at last forced him, with twelve others" who supported him "into an open Boat ... and . . . they were never heard of afterwards" (Snelgrave $1734,198) .^{32}$

Crews sometimes elected quartermasters who displayed particular valor or keen decision making to replace less capable or honorable captains. For example, when one pirate crew "went to Voting for a new Captain . . . the Quarter-Master, who had behaved so well in the last Affair . . . was chosen" (Johnson 1726-28, 479). This helped create competition among pirate officers that tended to check their abuses and encouraged them to serve the interests of their crews. ${ }^{33}$

Pirates took seriously the limitations they imposed on captains' authority through their system of checks and balances. A speech made by one of the pirates aboard Captain Bartholomew Roberts' ship testifies to this. As he told his crew, "should a Captain be so sawcy as to exceed Prescription at any time, why down with him! it will be a Caution after he is dead to his Successors, of what fatal Consequence any sort of assuming may be" (Johnson 1726-28, 194-95). This pirate was exag-

\footnotetext{
${ }^{32}$ In some cases, crews also physically punished their captains for behavior they deemed inconsistent with their interests. For example, Oliver La Bouche was deprived of his captain position and flogged for attempting to desert his crew (de Bucquoy 1744, 103; translated and quoted in Rogozinski 2000,177). Occasionally, crews also deserted predatory captains (Council of the Leeward Islands, May 18, 1699, Public Record Office, Colonial Office Papers, 152:3, no. 21).

${ }^{33}$ This competition likely explains the rarity of cases of captain-quartermaster collusion against crews.
} 
gerating - but only slightly. Crews quickly and readily deposed old captains and elected new ones when the former overstepped the limited power crews gave them.

The seriousness with which pirates sought to limit their captains' power is reflected in other ways as well. For instance, in contrast to merchant vessels, on pirate ships, captains were unable to secure special privileges for themselves at their crews' expense. Their lodging, provisions, and even pay were nearly the same as that of ordinary crew members. As Johnson described it, aboard pirate ships "every Man, as the Humour takes him . . . [may] intrude [the captain's] Apartment, swear at him, seize a part of his Victuals and Drink, if they like it, without his offering to find Fault or contest it" (1726-28, 213-14). In other cases, "the Captain himself not being allowed a Bed" had to sleep with the rest of the crew in far less comfortable conditions (Snelgrave 1734, 217). Or, as one pirate fellow-traveler marveled, "even their Captain, or any other Officer, is allowed no more than another Man; nay, the Captain cannot [even] keep his own Cabin to himself" (Downing [1737] 1924, 99; quoted in Rogozinski 2000, 175).

One pirate captive records an event in which the captains of a pirate fleet borrowed fancy clothes that were part of the loot their crews acquired in taking a recent prize. These captains hoped that their stolen finery would attract local women on the nearby shore. Although the captains intended only to borrow the clothes, the crews became outraged at their captains whom they saw as transgressing the limits of their narrowly circumscribed power. As the observer described it, "The Pirate Captains having taken these Cloaths without leave from the Quartermaster, it gave great Offence to all the Crew; who alledg'd, 'If they suffered such things, the Captains would for the future assume a Power, to take whatever they liked for themselves"' (Snelgrave 1734, 257). ${ }^{34}$

One can also get an idea of the effectiveness of piratical checks and balances by considering the remarks of one contemporary that point to the rarity of pirate captain predation. Perplexed by an anomalous pirate captain who abused his crew, he puzzled, "The captain is very severe to his people, by reason of his commission, and caries a very different form from what other Pirates use to do . . . often calling for his pistols and threatening any that durst speak to the contrary of what he desireth, to knock out their brains" (quoted in Rogozinski 2000, 139;

\footnotetext{
${ }^{34}$ This decentralization of authority and elimination of captain privilege aboard pirate ships were radical departures from conditions in the legitimate maritime world. Observers were therefore shocked at the incredible absence of hierarchy aboard pirate ships. Commenting on their democratic form of governance, e.g., the Dutch governor of Mauritius marveled, "Every man had as much say as the captain" (quoted in Ritchie 1986, 124).
} 
see also Deposition of Benjamin Franks, October 20, 1697, Public Record Office, Colonial Office Papers, 323:2, no. 124). ${ }^{35}$

This success helps explain why, counterintuitively, "the People [pirates overtook] were generally glad of an opportunity of entring with them" (Snelgrave 1734, 203). Indeed, pirates frequently "strengthen'd themselves with a great many fresh Hands, who most of them enter'd voluntarily" (Johnson 1726-28, 170; see also 228; Deposition of Jeremiah Tay, July 6, 1694, Suffolk Court Files, no. 3033, paper 6; Colonial Office Papers, May 31, 1718, fol. 18). ${ }^{36}$

\section{B. Pirate Constitutions}

Pirates' system of checks and balances effectively prevented captains from preying on their crews. However, a significant problem remained. In vesting many of the powers captains typically held in quartermasters instead, what was to prevent quartermasters from abusing their authority to privately benefit at crews' expense?

As discussed above, quartermasters had numerous roles aboard pirate ships. They were in charge of the distribution of booty and provisions, conflict resolution, and crew member punishment. This gave them ample latitude to prey on crews. I have already discussed one check on quartermaster predation, which also checked captain predation-democratic elections. As with their captains, pirate crews elected quartermasters and could depose them if they overstepped their authority.

But what precisely did this include? Were, for instance, quartermasters free to divide booty and provisions as they saw fit? Could they punish crew members at their discretion? Furthermore, according to what "laws" were they supposed to adjudicate disputes between those on board?

After all, not only were pirates afraid of captain predation; they opposed any situation that threatened to jeopardize their ability to cooperate for organized banditry, including the institution of the quartermaster. To solve this problem, pirate crews forged written constitutions that specified their laws and punishments for breaking these laws and more specifically limited the actions that quartermasters might take in carrying out their duties.

Pirate constitutions originated with "articles of agreement" followed

\footnotetext{
${ }^{35}$ The captain referred to here is William Kidd, a privateer-turned-pirate, who was ultimately executed for his crimes. Notably, Kidd's privateer ship was financed by absentee owners.

${ }^{36}$ Many individuals ostensibly forced to join pirate crews in fact joined voluntarily. Officially, they asked to be "forced" and occasionally put up a show to their comrades to this effect so that in the event their pirate crew was ever captured, they could claim that they were compelled as a defense (Pringle 1953; see also Rankin 1969).
} 
on buccaneer ships in the seventeenth century. The buccaneers called their articles a chasse-partie. These articles specified the division of booty among the officers and crew along with other terms of the buccaneers' organization. All sea bandits followed the basic rule of "no prey, no pay." Unless a pirating expedition was successful, no man received any payment.

Exquemelin $(1678,71-72)$ describes the chasse-partie that governed his crew's expedition in detail:

The buccaneers resolve by common vote where they shall cruise. They also draw up an agreement or chasse partie, in which is specified what the captain shall have for himself and for the use of his vessel. Usually they agree on the following terms. Providing they capture a prize, first of all these amounts would be deducted from the whole capital. The hunter's pay would generally be 200 pieces of eight. The carpenter, for his work in repairing and fitting out the ship, would be paid 100 or 150 pieces of eight. The surgeon would receive 200 or 250 for his medical supplies, according to the size of the ship.

Then came the agreed awards for the wounded, who might have lost a limb or suffered injuries. They would be compensated as follows: for the loss of a right arm, 600 pieces of eight or six slaves; for a left arm 500 pieces of eight or five slaves. The loss of a right leg also brought 500 pieces of eight or five slaves in compensation; a left leg 400 or four slaves; an eye, 100 or one slave, and the same award was made for the loss of a finger. If a man lost the use of an arm, he would get as much as if it had been cut off, and a severe internal injury which meant the victim had to have a pipe inserted in his body would receive 500 pieces of eight or five slaves in recompense.

These amounts having first been withdrawn from the capital, the rest of the prize would be divided into as many portions as men on the ship. The captain draws four or five men's portions for the use of the ship, perhaps even more, and two portions for himself. The rest of the men share uniformly, and the boys get half a man's share.

. . . When a ship is robbed, nobody must plunder and keep his loot to himself. Everything taken-money, jewels, precious stones and goods-must be shared among them all, without any man enjoying a penny more than his fair share. To prevent deceit, before the booty is distributed everyone has to swear an oath on the Bible that he has not kept for himself so much as the value of a sixpence, whether in silk, linen, wool, gold, silver, jewels, clothes or shot, from all the capture. And should 
any man be found to have made a false oath, he would be banished from the rovers, never more be allowed in their company.

Over time, the buccaneers institutionalized their articles of agreement and social organization. The result was a system of customary law and metarules called the "Custom of the Coast," or the "Jamaica Discipline."

Eighteenth-century pirates built on this institutional framework in developing their own constitutions. Pirates created them "for the better Conservation of their Society, and doing Justice to one another" (Johnson 1726-28, 210). The basic elements of pirate constitutions displayed remarkable similarity across crews (Rediker 1987, 261). In describing the articles on Captain Roberts' ship, for instance, Johnson refers to "the Laws of this Company . . principle Customs, and Government, of this roguish Commonwealth; which are pretty near the same with all Pyrates" (1726-28, 213).

Frequent intercrew interactions led to information sharing that facilitated constitutional commonality. ${ }^{37}$ More than 70 percent of AngloAmerican pirates active between 1716 and 1726, for example, can be connected back to one of three pirate captains: Benjamin Hornigold, George Lowther, or Edward Low (Rediker 1987, 267). Thus, a significant proportion of all pirates during this period were associated with one another in some way, via traveling on the same ship, in concert with other ships, and so forth.

Articles of agreement required unanimous consent. Consequently, pirates democratically formed them in advance of launching pirating expeditions. "All [pirates] swore to 'em," sometimes on a Bible or, for one pirate crew, "upon a Hatchet for want of a Bible." The crew forged its articles alongside the election of a captain, quartermaster, and occasionally other smaller officers. Pirates sought agreement on their articles ex ante "to prevent Disputes and Ranglings afterwards" (Johnson 1726-28, 342). In the event a pirate disagreed with their conditions, he was free to search elsewhere for more satisfactory terms. ${ }^{38}$

\footnotetext{
${ }^{37}$ A letter from colonial governor Alexander Spotswood to the Board of Trade highlights the effectiveness of pirates' information-sharing network. Spotswood, who having "been markt as the principle object of their vengeance, for cutting off their arch pirate Thatch [a.k.a. Blackbeard]" complained of finding a place to escape to "where neither Master nor Sailors know me, \& so may possibly escape the knowledge of ye pirates" (Colonial Office Papers, June 16, 1724, 5/1319: fols. 190-92; quoted in Rediker 1987, 254, 134).

${ }^{38}$ Pirate ships often required crew members to agree to stay on until a certain sum was earned or an expedition completed. However, if a ship became too crowded or some other compelling reason came along for a crew to split, it did so. In this case, new articles were drawn up and pirates had the option to sign on with the new crew or stay with the old. There do not appear to be any cases of pirate constitutions being altered or amended midcruise. The status of forced men on pirate ships seems to have varied. Some appear to have been compelled to sign the ship's articles. Others were not compelled to do so but did not have a vote in the company's affairs until they signed (Rediker 2004, 79-81).
} 
When multiple pirate ships joined together for an expedition, they created similar articles establishing the terms of their partnership. Upon encountering one another at Grand Cayman, for example, Captain George Lowther and Edward Low's pirate crews forged such an agreement. Lowther "offering himself as an Ally; Low accepted of the Terms, and so the Treaty was presently sign'd without Plenipo's or any other Formalities" (1726-28, 319).

Likewise, crews that objected to the proposed articles or some other element of an intended multiship expedition were free to depart peaceably. In one such case, for example, "a Spirit of Discord" emerged between three pirate crews sailing in consort "upon which ... [they] immediately parted, each steering a different Course" (Johnson 172628, 175).

Charles Johnson's records contain several examples of pirate constitutions, through which, as one court remarked, these rogues were "wickedly united, and articled together" (Johnson 1726-28, 253). Consider, for instance, the articles aboard Captain Roberts' pirate ship, as relayed by Captain Johnson (211-12):

I. Every Man has a Vote in the Affairs of Moment; has equal Title to the fresh Provisions, or strong Liquors, at any Time seized, and may use them at Pleasure, unless a Scarcity make it necessary, for the Good of all, to vote a Retrenchment.

II. Every Man to be called fairly in Turn, by List, on board of Prizes, because, (over and above their proper Share) they were on these Occasions allowed a Shift of Cloaths: But if they defrauded the Company to the Value of a Dollar, in Plate, Jewels, or Money, Marooning was their Punishment. If the Robbery was only betwixt one another, they contented themselves with slitting the Ears and Nose of him that was Guilty, and set him on Shore, not in an uninhabited Place, but somewhere, where he was sure to encounter Hardships.

III. No person to Game at Cards or Dice for Money.

IV. The Lights and Candles to be put out at eight a-Clock at Night: If any of the Crew, after that Hour, still remained enclined for Drinking, they were to do it on the open Deck.

V. To keep their Piece, Pistols, and Cutlash clean, and fit for Service.

VI. No Boy or Woman to be allowed amongst them. If any Man were found seducing any of the latter Sex, and carry'd her to Sea, disguised, he was to suffer Death.

VII. To Desert the Ship, or their Quarters in Battle, was punished with Death or Marooning. 
VIII. No striking one another on board, but every Man's Quarrels to be ended on Shore, at Sword and Pistol.

IX. No Man to talk of breaking up their Way of Living, till each shared a $1000 \mathrm{l}$. If in order to this, any Man should lose a Limb, or become a Cripple in their Service, he was to have 800 Dollars, out of the publick Stock, and for lesser Hurts, proportionately.

X. The Captain and Quarter-Master to receive two Shares of a Prize; the Master, Boatswain, and Gunner, one Share and a half, and other Officers one and a Quarter [everyone else to receive one share].

XI. The Musicians to have Rest on the Sabbath Day, but the other six Days and Nights, none without special Favour.

Several important features stand out from these examples of pirate articles. First, they created a democratic form of governance and explicitly laid out the terms of pirate compensation. This was to clarify the status of property rights aboard pirate ships and to prevent officers, such as the captain or quartermaster, from preying on crew members. In particular, making the terms of compensation explicit helped to circumscribe the quartermaster's authority in dividing booty.

When booty was indivisible or there was question as to its value and thus how many shares it counted for in payment, pirates sold or auctioned the troublesome items and distributed the divisible proceeds accordingly (Snelgrave 1734; Rogozinski 2000, 169). This practice prevented conflict between crew members. More important, it constrained the discretion of the quartermaster, who might otherwise be in a position to circumvent the terms of compensation when loot was indivisible or of ambiguous value.

Second, pirate articles prohibited activities that generated significant negative externalities and threatened the success of criminal organization aboard their ships. Thus, pirate articles required crew members to keep their weapons in good working order; on Roberts' ship limited drunken raucousness to allow nonparticipant pirates to get sufficient sleep, and to "give a Check to their Debauches" (Johnson 1726-28, 211); prohibited onboard fighting that might jeopardize the entire crew's ability to function; and prohibited activities, such as gambling, that were likely to lead to onboard brawls. On similar grounds, crews' articles often prohibited women (and young boys), who it was thought would invite conflict or tension among crew members aboard their ships. "This being a good political Rule to prevent disturbances amongst them, it is strictly observed" (Snelgrave 1734, 256-57; see also Johnson 1726$28,212)$.

In the same way, some pirate ships forbade activities such as firing 
one's guns or smoking in areas of the ship that carried highly flammable goods, such as gunpowder. According to the articles aboard John Phillips' Revenge, for example, "That Man that shall snap his Arms, or smoak Tobacco in the Hold without a Cap to his Pipe, or carry a Candle lighted without a Lanthorn, shall suffer the same Punishment as in the former Article" (Johnson 1726-28, 342-43).

Third, pirate constitutions contained articles that provided incentives for crew member productivity and prevented shirking. One manifestation of this was their creation of social insurance for pirates injured during battle. As in the examples from Exquemelin and Roberts above, articles specified in detail what a lost arm was worth, a lost leg, and so on. They even went as far as to assign different insurance values depending on whether it was, for instance, the right or left appendage that was mutilated or lost, according to the importance pirates assigned to these body parts.

Another manifestation of these incentive provisions was the use of bonuses for crew members who displayed particular courage in battle, were the first to spot potential targets, and so forth. Because pirate crews were large, quartermasters could not easily monitor individual pirates' effort. As I discuss below, this is why pirates used profit sharing rather than fixed wages for payment.

The problem with a share system is that it can create incentives for free riding. Further, one team member's laziness directly reduces the income of the others. To deal with this, pirates, like privateers and whalers, who also used a share system, created bonuses. According to the rule aboard Exquemelin's buccaneering vessel, for instance, "Those who behaved courageously and performed any deed of extraordinary valour, or captured a ship, should be rewarded out of the common plunder" $(1678,156)$. Or, as Johnson records, "It must be observed, they [pirates] keep a good Look-out; for, according to their Articles, he who first espies a Sail, if she proves a Prize, is entitled the best Pair of Pistols on board, over and above his Dividend" (1726-28, 191).

Finally, pirate articles stipulated punishments for failure to adhere to their rules. As discussed above, for more minor infractions, crews typically delegated punishment power to the ship's democratically elected quartermaster. As Johnson described it, the quartermaster "acts as a Sort of civil Magistrate on board a Pyrate Ship" $(1726-28,213) \cdot{ }^{39}$ In the case

\footnotetext{
${ }^{39}$ When this failed, the quartermaster refereed a duel between the parties, which would take place on land so as not to destroy the ship. "The Quarter-Master of the Ship, when the Parties will not come to any Reconciliation, accompanies them on Shore with what Assistance he thinks proper, and turns the Disputants Back to Back, at so many paces Distance: At the Word of Command, they turn and fire immediately . . . . If both miss, they come to their Cutlashes, and then he is declared Victor who draws the first blood" (Johnson 1726-28, 212; see also 339).
} 
of more severe infractions, crew members voted on punishments. In both cases pirate crews tended to follow the punishments for various infractions identified in their articles. By specifying punishments in their articles, crews were able to limit the scope of quartermasters' discretion in administering discipline, checking quartermasters' power for abuse.

Punishments for article violations varied from physical torture, such as "slitting the Ears and Nose of him that was Guilty," to marooninga practice Captain Johnson described as the "barbarous Custom of putting the Offender on Shore, on some desolate or uninhabited Cape or Island, with a Gun, a few Shot, a Bottle of Water, and a Bottle of Powder, to subsist with or starve" $(1726-28,211) .{ }^{40}$ On Captain Phillips' ship, for example, article violations were punished with "Moses's Law (that is, 40 Stripes lacking one) on the bare back" (342-43).

In this sense, "Pirates exercised greater cruelty in maintaining discipline among themselves than in their treatment of prisoners" (Rankin 1969, 37). Pirates considered theft aboard their ships especially heinous. Their articles reflected this and frequently punished theft with torture, marooning, or death. To help keep themselves honest, some crews used random searches to hunt for anyone who might be holding back loot (Exquemelin 1678, 205-6) ${ }^{41}$ To ensure that the quartermaster did not hide booty from the crew, some pirates prohibited their valuable plunder from being kept under lock and key. As pirate Peter Hooff described the situation on Captain Sam Bellamy's Whydah, for instance, the "money was kept in Chests between Decks without any Guard, but none was to take any without the Quarter Masters leave" (quoted in Rediker 2004, 67; see also Marx 1996a, 44).

Since pirate articles tended to be short and simple, they could not cover all possible contingencies that might affect a crew. In this sense they were always incomplete. To deal with this, when a significant issue emerged, the crew gathered to act as a kind of judiciary to interpret or apply the ship's articles to situations not clearly stipulated in the articles themselves: "In Case any Doubt should arise concerning the Construction of these Laws, and it should remain a Dispute whether the Party had infringed them or no, a Jury was appointed to explain them, and bring in a Verdict upon the Case in Doubt" (Johnson 1726-28, 213). Through this "judicial review" process, pirate crews were able to further limit quartermasters' discretionary authority, restraining the potential for quartermaster abuse.

The historical record points to the effectiveness of pirate constitutions

\footnotetext{
${ }^{40}$ Marooning was sometimes coupled with ostracism in the event that the transgressor managed to survive. See, e.g., Exquemelin $(1678,72)$.

${ }^{41}$ Oath taking was commonly used among pirates as well as a method of staking one's reputation to help enforce piratical articles and custom. See, e.g., Exquemelin (1678, 68, $71-72,100,104,156,161)$.
} 
in this capacity, evidenced by the rarity of accounts of quartermaster abuse. Equally important, in the infrequent event that abuse did occur, the evidence indicates that crews successfully removed abusive quartermasters from power. For example, in 1691 quartermaster Samuel Burgess cheated his crew in the division of food. In response, his crew marooned him (Rogozinski 2000, 177).

The evidence also suggests that piratical articles were successful in preventing internal conflict and creating order aboard pirate ships. Pirates, it appears, strictly adhered to their articles. According to one historian, pirates were more orderly, peaceful, and well organized among themselves than many of the colonies, merchant ships, or vessels of the Royal Navy (Pringle 1953; Rogozinski 2000). As an astonished pirate observer put it, "At sea, they perform their duties with a great deal of order, better even than on the Ships of the Dutch East India Company; the pirates take a great deal of pride in doing things right" (de Bucquoy 1744, 116; translated and quoted in Rogozinski 2000, viii).

Though it is strange to think about such order prevailing among pirates, the peculiarity fades when one recognizes that their organized criminal enterprise's success depended on it. The remark of one perceptive eighteenth-century observer indicates precisely this. As he put it, "great robbers as they are to all besides, [pirates] are precisely just among themselves; without which they could no more Subsist than a Structure without a Foundation" (Slush 1709, viii; quoted in Rediker 1987, 287).

The fact that pirate crews unanimously consented to the articles that governed them, ex ante, also plays an important role in explaining their success. Pirates recognized that "it was every one's Interest to observe them, if they were minded to keep up so abominable a Combination" (Johnson 1726-28, 210). Since pirates agreed to these rules before sailing, rules were largely self-enforcing once in place.

\section{Was Pirate Organization Efficient?}

In light of the sharp contrast between merchant and pirate ship organization, an important question arises concerning the efficiency of pirate institutions. After all, merchant ships were legitimate vessels and therefore had the government's formal enforcement power at their disposal. This gave them a wider range of organizational options than pirates, who were criminals and therefore did not have the government backing that afforded the same organizational choices. One possibility, then, is that pirate organization merely reflects this smaller menu of opportunities. Perhaps if pirates could have relied on government enforcement, they too would have opted for merchant ship-like institutions.

Alternatively, pirate ship organization was an efficient institutional 
response to the unique economic situation pirates faced, quite apart from their inability to rely on government. Although pirates faced a constraint that merchant ships did not-inability to rely on government-as discussed above, merchant ships faced a constraint that pirate ships did not-the need to solve an owner-crew principal-agent problem. Given the very different economic situations pirate and merchant ships confronted in this regard, it would not be surprising if the efficient mode of organizing these ships was different as well-this difference being driven by the economic differences between the two rather than by their different legal status.

\section{A. Pirate Booty}

As a first cut at this issue we can look to the success of piratical expeditions. If pirates seized only small prizes, or no prizes at all, clearly their organization was not an effective one. On the other hand, if pirates succeeded in taking very valuable prizes, our confidence in pirates' organizational efficiency should grow.

The evidence suggests that if pirates' inability to organize autocratically was inhibiting piratical efficiency, it could not have been doing so greatly. Although we do not have data that would allow us to compute anything like the average pirate's wage, what evidence is available suggests that incredibly large pirate prizes were not unheard of.

Of course, this evidence must be interpreted with caution. These seizures were recorded precisely because of their spectacular size. More common were undoubtedly more modest prizes. Nevertheless, the examples we have are enough to point to the significant success of piratical plunder in some cases and the opportunity piracy offered sailors for becoming incredibly wealthy.

"At a time when Anglo-American seamen on a trading voyage to Madagascar were collecting less than twelve pounds sterling a year . . . the deep-water pirates could realize a hundred or even a thousand times more" (Marx 1996c, 141). In 1695, for example, Henry Every's pirate fleet captured a prize carrying more than $£ 600,000$ in precious metals and jewels. The resulting share-out earned each member of his crew $£ 1,000$ (Konstam 2007, 98), the equivalent of nearly 40 years' income for an able merchant seaman at the time. In the early eighteenth century, Captain John Bowen's pirate crew plundered a prize "which yielded them 500 l. per Man." Several years later Captain Thomas White's crew retired to Madagascar after a marauding expedition, each pirate having earned £1,200 from the cruise (Johnson 1726-28, 480, 485). In 1720, Captain Christopher Condent's crew seized a prize that earned each pirate $£ 3,000$. Similarly, in 1721, Captain John Taylor and Oliver La Bouche's pirate consort earned an astonishing $£ 4,000$ for each crew 
member from a single attack (Marx 1996c, 161, 163). Even the small pirate crew captained by John Evans in 1722 took enough booty to split "nine thousand Pounds among thirty Persons"—or $£ 300$ a pirate-in less than six months "on the account" (Johnson 1726-28, 340).

To put these earnings in perspective, compare them to the able merchant seaman's wage over the same period. Between 1689 and 1740 this varied from 25 to 55 shillings per month, a meager $£ 15$ to $£ 33$ per year (Davis 1962, 136-37).

In the absence of data for a larger number of pirate hauls, it is not possible to say whether the average seventeenth- or eighteenth-century pirate consistently earned more than the average seventeenth- or eighteenth-century merchant sailor. It is certainly possible that this was the case, however. As one pirate testified at his trial, for instance, "it is a common thing for us [pirates] when at Sea to acquire vast quantities, both of the Metal that goes before me [silver, referring to the silver oar of the Admiralty court], and of Gold" (quoted in Hayward 1735, I:45).

This pirate's remark may very well reflect his desire to impress the court more than it reflects piracy's profitability. Still, what the evidence on piratical plunder does clearly point to is the tremendous potential "upside" of piratical employment. Unlike employment as a merchant sailor, which guaranteed a low, if regular, income, a single successful pirating expedition could make a sailor wealthy enough to retire. This is no doubt largely the reason why, as one eighteenth-century colonial governor remarked, "so many are willing to joyn them [pirates] when taken" (Colonial Office Papers, May 31, 1718, fol. 18; quoted in Rediker 1987, 260).

If pirates did in fact earn substantially more than their legitimate counterparts, this raises the question of why more merchant sailors did not join the ranks of the pirates, eliminating any difference between pirate and merchant sailor wages. Bearing in mind again that we cannot know for certain whether or not the average pirate earned more than the average merchant sailor, there are two reasons sailors did not flock in greater numbers to life beneath the black flag even if this were the case.

The first was simply the risk of being caught. Piracy was a capital offense. In the eighteenth century, if a sailor was found guilty of piracy, he was hanged. Although pirates largely escaped the arm of the law in the seventeenth century, by the third decade of the eighteenth century England's renewed campaign against sea banditry was successfully capturing and hanging pirates regularly, rendering piracy an exceptionally dangerous employment.

Second, a merchant sailor who entered piracy had to be willing to plunder other ships, murder innocents, and brutally torture resisters. Although many sailors were surely drawn to the idea of piracy by the 
prospect of riches, in light of the brutal features of piratical employment, it is not surprising that many sailors were unwilling to become sea marauders despite the potentially superior pay.

\section{B. A Comparison to Privateer Organization}

Pirates' plunderous success does not necessarily point to their organization's efficiency, however. Pirates may have been quite successful despite their institutions rather than because of them. Ideally, to assess pirate organization's efficiency we would want to see how marine vessels that engaged in the same economic activity as pirates, violently taking prizes-but did so legitimately and thus enjoyed government enforcement-were organized. If we could identify such vessels and they exhibited some of pirate ships' important institutional features, we could more confidently conclude that pirate organization reflected an efficient response to the economic activity pirates were engaged in, not merely the fact that they did not enjoy government support.

Fortunately, such vessels exist and indeed operated contemporaneously with seventeenth- and eighteenth-century pirate ships. These vessels are privateers. Privateers were private warships licensed by governments to harass the merchant ships of enemy nations. Privateers shared a predetermined portion of the proceeds from this activity with the commissioning government. ${ }^{42}$ Their licenses, sometimes called "letters of marque," granted them official permission to plunder enemy merchant ships and established their legitimacy under the law. ${ }^{43}$ Thus, the institutions and arrangements that privateers used to regulate their ships were legal agreements, enforceable by the commissioning government.

Privateers, like merchant ships, were owned by absentee merchants. Consequently, privateers did not have elected captains or a system of separated powers, as pirate ships did. Owing to the absentee ownership structure privateers shared with merchant ships, the principal-agent problem privateers confronted was similar to the one merchant ships faced. A privateer captain who could be popularly deposed or did not wield absolute authority over his crew would undermine the vessel's profitability for its owners. Given the chance, crew members would elect lax, liberal, and corrupt captains who would allow sailors to relax when they desired, have free reign with provisions, lie to the vessel's owners

${ }^{42}$ However, in England, the Prize Act of 1708 entitled privateers to the full value of prizes they took.

${ }^{43}$ There were two kinds of privateers. The first were "full-time" privateers, which sailed exclusively for the purpose of prize taking. The second kind were merchant ships with permission to take prizes they might happen upon and profitably seize in the course of their shipping activity (Rodger 2006, 156). My discussion is concerned with the former, since the latter were in the business of merchant shipping rather than the business of prize taking. 
about what plunder they had taken so the crew could hold back a greater share for itself, and so forth. Thus, a variant on the same principalagent problem merchant ships confronted, which required autocratic captains for its solution, also plagued privateers to a large extent, necessitating autocratic captains on these vessels as well. ${ }^{44}$

Despite this important difference, privateers and pirate ships shared several significant economic features. Most notably, both engaged in plunder. Because of this, privateers, like pirate ships, carried large crews, sometimes of 100 men or more. This was so that they could overcome the smaller merchant ships they preyed on. Similarly to pirate vessels, the size of privateers made it difficult for captains to monitor sailors' effort on these ships. This led privateers to use a pirate-like share system of payment instead of the fixed wages merchant ships used owing to their dramatically smaller size. ${ }^{45}$

Privateers' use of the share system is important because we know that since they enjoyed the full benefit of government enforcement, the absence of such enforcement could not be the reason privateers adopted this compensation scheme. This suggests that the share system's efficiency for pirates was rooted in a specific economic situation pirates confronted (large crews engaged in plunder), shared by privateers, not in an inability to rely on state enforcement.

Privateers also used constitutions similar to those on pirate ships. Woodes Rogers, for instance, records his crew's adoption of a "Constitution," as he called it, for the privateering expedition he commanded between 1708 and 1711 (Rogers [1712] 2004, 7). Several of this constitution's articles resemble those in pirate constitutions. Article 1, for example, specifies the division of plunder between crew members. Article 3 states "that if any Person on board . . . do conceal any Plunder

\footnotetext{
${ }^{44}$ Some privateer captains, such as Woodes Rogers, consulted a council of their fellow officers in making decisions. But democratic voice did not extend to the crew. It should be noted, however, that late seventeenth-century and early eighteenth-century sea raiders who blurred the distinction between pirates and privateers by sailing sometimes with a commission and many other times without typically employed piratical governance institutions.

${ }^{45}$ Privateers were not the only legitimate vessels that used the pirates' share system. Whaling vessels did as well. Although whaling vessels were smaller than pirate ships or privateers, they were typically larger than merchant ships, again making it more difficult to monitor sailor effort. This necessitated share payment, called a "lay," instead of fixed monthly or lump-sum wages (Davis, Gallman, and Gleiter 1998). Navy ships also relied partially on a share system to compensate sailors. Although in peacetime sailors received fixed monthly wages, in wartime they received both monthly wages and a share of their prizes' proceeds, as well as "head money" for each of the enemy sailors these prizes carried. Since naval vessels were very large, incentive-based pay helped to overcome the difficulty of monitoring individual sailors. Additionally, navy vessel pay scales (including prize shares) were steeply skewed according to rank. To elicit crew members' full effort, navy vessels thus combined incentive pay in the context of a tournament system. See, e.g., Benjamin and Thornberg (2007).
} 
exceeding one Piece of Eight in value, 24 hours after the Capture of any Prize, he shall be severely punish'd, and lose his Shares of the Plunder." Article 6 stipulates "that a Reward of twenty Pieces of Eight shall be given to him that first sees a Prize of good Value, or exceeding 50 Tuns in Burden." Like pirate articles, which required unanimous consent, this privateering constitution, Rogers tells us, was similarly signed by every member of the crew "without any Compulsion" (23).

Since Rogers' expedition enjoyed the full protection of government enforcement, this constitution could not have been adopted because the vessels did not have state backing. Instead, such privateer constitutions must have been efficient for reasons unrelated to this. Common obstacles faced by both pirates and privateers suggest what these reasons are.

First and foremost, both pirates and privateers were in the business of sea banditry. Because the goods they dealt with and carried were always stolen, property rights to these goods could be somewhat unclear. For instance, if upon boarding a vessel a pirate or privateer came upon some valuable, was it his to keep? Or was this part of the common loot to be divided among the crew? Once the stolen booty was transferred to the pirate or privateer ship, was it fair game? After all, no one on the pirate or privateer ship could claim to legitimately own it. To clarify the status of property rights on their ships, both privateers and pirates used constitutions to make explicit crew member property rights to plunder.

Contrast this situation with the status of property rights on merchant vessels. On these ships, property rights were totally clear. The cargo they carried clearly belonged to the ships' owners (or their customers) and not the crew. Explicating the property rights over the goods merchant ships carried was therefore unnecessary, and for this reason, merchant ships did not do so.

Similarly, since both pirates and privateers used a share system to compensate crew members, the laziness of one crew member directly affected the payment of the others. To attenuate this problem and elicit full crew member effort, both privateers and pirates constitutionally codified bonuses on their ships. Contrast this situation again with the one on merchant ships, which used fixed wages. Here, each sailor's income was independent of his fellow crew members' behavior. Thus, bonuses were unnecessary. ${ }^{46}$

The similarities between certain aspects of pirate and privateer institutions, as well as the differences between their shared institutions and

\footnotetext{
${ }^{46}$ Ship captains sometimes received bonuses, however. "Primage and average," for example, were paid to ship captains and constituted bonuses of a sort, though these were paid by the freighter rather than by the owners.
} 
those of merchant ships, suggests two important items. First, the institutional differences between pirate and merchant ships were driven at least in part by the different economic situations they confronted, not the difference in their ability to rely on government support. Second, at least some major features of pirate organization were efficient independent of pirates' inability to rely on government. Their efficiency derived from the particular economic situation pirate ships faced, which they shared partially with privateers.

On the other side of this, at least one important part of the economic situation pirates and privateers faced was very different: the ownership structure of their ships. In terms of this feature, privateers and merchant ships were similar, whereas pirate ships, which had no absentee owners, were very different. This explains why privateers and merchant ships both used autocratic captains, which they required to solve the ownercrew principal-agent problem they consequently faced. In contrast, since on pirate ships the principals were the agents, pirates could use a democratic system of separated power to constrain captain predation.

\section{A Comparison to Explorer Organization}

A crucial feature of pirate organization's efficiency was its ability, or inability, to facilitate crew cooperation. Since pirates lived and worked together in close quarters among fellow criminals for extended periods of time, their ability to cooperate for coordinated plunder was a critical determinant of their enterprise's success.

Merchant ships secured crew cooperation through the command of their autocratic captains. Indeed, as discussed above, merchant ships could not do without autocracy for this purpose. In contrast, pirate ships did not have the state backing required for autocratic organization. Although the evidence considered above suggests that pirates cooperated successfully under democratic organization, this fact raises the question of pirates' organizational efficiency.

Perhaps pirates could have secured even more cooperation had they been able to organize autocratically as merchant ships did and would have sought to secure cooperation this way if they could. Alternatively, pirates' organization may have been superior in creating crew cooperation, in which case pirates used it (at least partly) for this reason, not because autocratically organizing their ships was not an option. ${ }^{47}$ To get

\footnotetext{
${ }^{47}$ As for the organizational features discussed above, here too it is important to emphasize that if pirate organization was in fact superior in creating crew cooperation, this would not mean that merchant ship organization was inefficient for merchant ships. Merchant ships faced a different economic situation than pirates, most important, the ownercrew principal-agent problem. Constrained by the need to solve this problem, merchant ships could secure crew cooperation only through autocracy. Thus, even if it came at the
} 
at this issue we need to examine the comparative ability of autocratic and democratic ship organization to facilitate crew cooperation.

Since the difficulty of achieving crew cooperation likely varied according to the activities different kinds of vessels were engaged in, it is important to consider how autocratic versus democratic ship organization affected crew cooperation on vessels engaged in the same activity. Comparing cooperation on pirate and merchant ships, then, is not helpful. Further, since all pirate ships were organized democratically and all merchant ships were organized autocratically, we cannot gain insight into this question by looking only at pirate ships or only at merchant ships. ${ }^{48}$

Fortunately, a different kind of ship we have not yet considered provides an excellent case for examining this issue: explorer vessels. Explorer vessels are useful here for two reasons. First, between the sixteenth and twentieth centuries, explorer ships embarked on long, often grueling, voyages to uncharted waters. Their crews spent years together at sea under conditions in which cooperation was at a premium. Second, there is significant variation in the modes of organization explorers employed for this purpose. Some pursued more autocratic organization, as merchant ships did. Others pursued more democratic organization, as pirate ships did, and with differing success.

Unlike merchant, privateer, or pirate voyages, most explorer voyages did not seek profits. Their purpose was to discover (and sometimes claim) unknown parts of the world and then to report their findings to curious landlubbers. ${ }^{49}$ This is significant because in contrast to the vessel types considered thus far, economic concerns did not play a significant role in determining explorer organization.

Instead, the party organizing an exploratory expedition determined the ship's institutional organization. When government chiefly financed and organized an expedition, the explorer's institutions tended to reflect the autocratic institutions of the government's navy. The resulting organization was similar to that on merchant ships. When an adventurer himself chiefly organized and raised the finances for an expedition, the ship's institutions tended to be more democratic.

price of less crew harmony, for merchant ships, autocratic organization was still superior to democratic organization, which would have rendered merchant shipping unprofitable for owners.

${ }^{48}$ The Barbary pirates, who were really corsairs, did not organize democratically. However, this article is not concerned with them.

${ }^{49}$ Although some explorer voyages, such as Magellan's, certainly had as their ultimate goal discovery for the purpose of profit, the exploratory expedition itself was almost always a "nonprofit" voyage. In Magellan's case the attitude seemed to be, if the exploratory voyage itself makes money, all the better. But pure exploration for the purpose of future gain was the voyage's primary aim, even if, e.g., the exploratory voyage itself did cover its own costs. 
I consider five explorer voyages between the sixteenth and twentieth centuries. Government directly or indirectly organized three of these, which displayed autocratic organization: Ferdinand Magellan's threeyear voyage around the world between 1519 and 1522, James Cook's three-year voyage in search of "the Discovery of the Southern Continent" between 1768 and $1771,,^{50}$ and Robert F. Scott's Antarctic expedition in the Discovery between 1901 and 1904. Private adventurers organized the remaining two explorer voyages, which displayed more democratic organization: Roald Amundsen's search for the Northwest Passage in the Gjøa between 1903 and 1906 and Ernest Shackleton's Antarctic expedition in the Endurance between 1914 and 1916.

Magellan's voyage consisted of five ships carrying 270 men in total. The Spanish government organized his expedition hierarchically, consisting of lieutenants, masters, captains for each ship, and, at the apex, Magellan himself, "captain-general" of the voyage. The Crown appointed Magellan to this position and issued a long and detailed list of regulations (74 in all) governing the terms of the exploration and how it should proceed. Chief among these were the government's strict instructions to the crew "to defer to the opinion and order of Magellan" (Guillemard 1890, 127-28) and Magellan's "power of deciding and executing short and summary justice by sea or land in case of suits or disputes arising in the fleet" (Stanley 1874, xxxi).

As one of Magellan's crew members put it, "the captain ordered that his regulations ... be strictly observed" (Pigafetta [1525] 1994, 39). These regulations dictated the sail of the fleet's ships, the crew members' duties, and even crew members' ability to trade with and accept gifts from the exotic foreigners they encountered on their journey (72).

Although there was a division of labor on Magellan's voyage, there was no division of power. Ultimately, the captain-general's orders directed his subordinate officers, who in turn directed the crew. There was one instance of limited democracy on Magellan's journey, which occurred when Magellan unexpectedly died. The crew "made and elected two commanders" to operate in the absence of their captaingeneral (Pigafetta 1525, 88). However, this seems to be the only democratic moment in the voyage, which was otherwise governed autocratically.

The effectiveness of Magellan's autocratic organization was mixed. On the one hand, considerable crew member turmoil plagued his expedition, culminating in a violent mutiny of three of Magellan's five ships against the captain-general, ostensibly because he had put the crew on short rations. Magellan emerged victorious out of the violent mixup

\footnotetext{
${ }^{50}$ The other duty the Admiralty instructed Cook to accomplish was to charter King George's Island.
} 
and punished the mutineers, some by execution, others by imprisonment. Later in the voyage, one entire ship deserted Magellan's fleet.

However, it is important to be careful in interpreting this conflict as a sign of total failure. The magnitude of the venture must be kept in mind, and, ultimately, the voyage did return to Spain. This constituted the first circumnavigation of the globe, albeit one that claimed the lives of 252 of the 270 sailors who undertook it.

The British government organized Captain James Cook's expedition. In command of His Majestys Bark Endeavour, Cook's captainship combined the powers of commander and ultimate disciplinarian along the lines observed in the merchant and navy marine. Indeed, Cook's regulations of his crew drew explicitly on those in operation in the navy at the time. As he instructed his crew, for example, "if by neglect [any sailor] looseth any of his Arms or woorking tools, or suffers them to be stole [by natives where the ship stops], the full Value thereof will be charge'd against his pay according to the Custom of the Navy in such cases, and he shall receive further punishment as the nature of the offence may deserve" (Cook, April 17, 1769 [2000, 40]).

This regulation was one of five "Rules to be observ'd by every person in or belonging to His Majestys Bark the Endeavor, for the better establishing a regular and uniform Trade for Provisions \& w with the Inhabitants of Georges Island" (April 17, 1769, 39-40).

As on Magellan's fleet, Cook also made use of a division of labor, sometimes delegating punishment duties to his officers. But ultimately Cook dictated and enforced corporal punishment. As his journal entry dated November 30, 1768, records, for instance, "Punished Rob Anderson Seaman and Will Judge Marine with twelve lashes each, the former for leaving his duty a Shore and attempting to disert the Ship, and the latter for useing abusive language to the Officer of the Watch, and John Readon Boatswains Mate with twelve lashes for not doing his duty in punishing the above two Men" (22). Similarly, elsewhere Cook records, "Punished Rich Hutchins Seaman with 12 lashes for disobaying command," highlighting both the hierarchy of the ship's organization and Captain Cook's authority to administer punishments (April 16, $1769,44)$.

Cook successfully accomplished his voyage; but his journal suggests that crew cooperation and harmony were strained. Here, Cook records instances of disgruntled sailors, insolence, theft, and even intracrew murder (see, e.g., the entries for April 13, 1769, 38; June 21, 1769, 60; June 4, 1769, 55; June 19, 1769, 58; and March 26, 1769, 35).

The Royal Society and Royal Geographic Society organized Robert Scott's early twentieth-century Antarctic exploration and appointed Scott captain of the expedition. Like Cook, Scott was a navy officer. In addition to several nonnaval mariners, a number of other navy seamen 
manned Scott's Discovery, which observed the traditional naval hierarchy. For instance, Scott imprisoned the cook and later chained him to the deck for insubordination (Huntford 1999, 146).

Like Cook's expedition, Scott's also suffered from sailor discontent. As one of his sailors remarked, Scott's autocratic method of governing the ship "is causing a lot of discontent on the mess deck," that is, among the nonofficer crew. Another noted how the crew's men had become "short tempered and low spirited" (quoted in Huntford 1999, 151). The Discovery's troubles peaked when it became lodged in ice in the Ross Sea. In an embarrassing finale to the debacle, the Royal Navy had to rescue it.

Roald Amundsen's organization aboard the Gjøa provides an interesting contrast to Scott's. Amundsen's voyage took place only a few years after Scott's and sought to explore the Arctic. In contrast to the voyages discussed above, Amundsen organized his exploration on his own behalf. He was therefore not obliged to organize the Gjøa according to the navy pattern. On the contrary, he chose to organize his ship in a highly democratic, decentralized fashion, not unlike pirate organization. As Amundsen described his vessel's organization, "We have established a little republic on board Gjøa . . . A After my own experience, I decided as far as possible to use a system of freedom on board-let everybody have the feeling of being independent within his own sphere. In that way, there arises . . . a spontaneous and voluntary discipline, which is worth far more than compulsion . . . . The will to do work is many times greater and thereby the work itself" (quoted in Huntford 1999, $84)$.

As one sailor aboard the Gjøa commented, "No orders were given, but everyone seemed to know exactly what to do" (quoted in Huntford 1999, 84). Unlike Scott's voyage, Amundsen's proved exceedingly smooth. The crew was happy and the expedition successful.

When one of Scott's former sailors aboard the Discovery, Ernest Shackleton, decided to explore the Antarctic himself, he also employed a more democratic organization for his vessel, the Endurance. Shackleton did not allow his crew to elect any of the ship's officers; but he did appoint his second in command, Frank Wild, to act as an arbitrator for the ship's men, removing himself from this authority. Shackleton set routines for his men and generally directed their activities. However, he assigned his men to the unpleasant and more pleasant tasks on the ship in shifts, regardless of their status, rather than basing their assignments on rank.

As one of his crew members observed, "When Shackleton took over control of the ship, the ship officers had to climb down a peg or two." According to him, "The ship's officers became units with no more authority than the rest of the crowd, and their position on the floe was 
the same" (quoted in Morrell and Capparell 2002, 89, 134). Officers and nonofficers received identical victuals and were treated equally in all other affairs.

Shackleton's quasi-democratic organization aboard the Endurance created good order and cooperation among the crew. As Thomas OrdeLees, a crew member of the Endurance, commented, for example, "We seem to be a wonderfully happy family but I think Sir Ernest is the real secret of our unanimity." Similarly, as another sailor recorded, "We are now six months out from England and during the whole of this time we have all pulled well together and with an almost complete lack of friction" (quoted in Morrell and Capparell 2002, 99).

The evidence from the five explorers considered here suggests that democratic or self-governing vessel organization, such as the kind pirates used, facilitated crew cooperation at least as successfully as autocratic vessel organization, and probably more so. Magellan, Cook, and Scott each seemed to face greater problems maintaining accord on their ships than Amundsen or Shackleton. Since pirates did not require autocratic organization to overcome the owner-crew principal-agent problem that merchant ships confronted, this suggests that even if pirates had government enforcement at their disposal, they would likely have opted for a democratic organization, such as the one they used. Although it is of course not possible to establish this definitively, it does not seem likely, then, that autocratic organization was in fact superior in this regard and that pirates would have used it if only they enjoyed government support.

The case of explorers also sheds light on the issue of captain predation. In contrast to merchant ships, there does not appear to have been a problem of captain predation on democratic or autocratic explorer vessels. Only on Magellan's voyage is there evidence that the crew suspected captain self-dealing, and here the charge seems to be unfounded (see, e.g., Guillemard 1890).

An important economic difference between merchant ships, on the one hand, and even autocratically organized explorer vessels, on the other, suggests itself as the likely reason for this. With the exception of Magellan, none of the explorer captains considered above stood to directly profit from cutting crew member rations, shorting crew members their pay, and so forth. These explorer captains were not residual claimants of their voyages, as merchant ship captains were.

Explorer captains gained very little if upon their vessels' return they had succeeded in defrauding the crew out of victuals or wages ${ }^{51}$ The expedition's costs were borne largely by external financiers who did not

\footnotetext{
${ }^{51}$ Although he may not benefit monetarily, a predatory captain might still have some incentive to pinch provisions to make more available to himself, however.
} 
"invest" in the expedition for profit. Further, the explorer captains themselves did not aim at turning a profit on the exploratory voyage itself. They therefore had little incentive to prey on their crew members.

Magellan is somewhat of an exception in this regard in that, under the terms of his agreement with the Spanish Crown, he was to receive 20 percent of any net proceeds his expedition directly generated. Thus, he could have tried to generate larger gains for himself by, for instance, illegitimately cutting crew member rations, which, as noted above, some crew members (wrongly) accused him of. However, Magellan's payoff of preying on his crew in this way paled in comparison to his payoff of making the exploration a successful one.

According to his agreement with Spain, if Magellan succeeded in discovering any new isles or countries, he was perpetually entitled to one-twentieth of all revenue they generated for Spain. Further, if his exploration succeeded in forging a route to the Spice Islands, he would be allowed to send 1,000 ducats' worth of goods on every Spanish armada sent to trade with the islands. However, to reap these much greater financial rewards, Magellan had to keep his crew intact sufficiently to weather the long and onerous voyage. Since cheating crew members would have seriously threatened this already difficult task, it was not in Magellan's greater financial interest to do so.

This absence of predatory incentives for captains on explorers stands in stark contrast to the situation on merchant ships in which every voyage's purpose was to make money, and absentee owners and shareholder captains often stood to directly profit from predation. Thus, while autocratic organization opened the door for captain abuse on merchant ships, it did not seem to do so significantly on explorer ships.

\section{Conclusion}

Over the last decade or so there has been a resurgence of piracy off the horn of Africa and in the Straits of Malacca (see, e.g., Gottschalk and Flanagan 2000; Burnett 2002; Langewiesche 2004). Like seventeenth- and eighteenth-century pirates, the modern variety choose to plunder ships in waters in which government enforcement is weak, such as those around Somalia and Indonesia, and commercial vessels are abundant.

Beyond this, however, modern pirates share little in common with their predecessors. Seventeenth- and eighteenth-century pirates lived together for long periods of time at sea. Although they retired to land between expeditions, they spent much of their time together prowling the expanses of the ocean in search of prey. Because of this, their ships formed miniature "floating societies." Like all societies, pirates' floating 
ones also required social rules and governance institutions if pirates were to maintain their "abominable combination."

In contrast, modern pirates spend almost no time together on their ships. Their "raids" take one of two forms. The first and most common method constitutes little more than maritime muggery. Pirate "crews" of two to six hop in small speedboats with guns; pull alongside legitimate ships, usually in territorial waters close to the coast; and threaten their prey at gunpoint to give up their watches, jewelry, and whatever money the boat may be carrying. They then return to their villages on the coast, where they live among nonpirates and resume regular employment.

These pirates do not live, sleep, and interact together on their ships for months, weeks, or even days on end. They therefore do not constitute a society and face few, if any, of the problems of social cooperation and order their forefathers did.

The second and far less common method of modern piracy is somewhat different. Crews again are small-between five and 15 men-and spend very little time together at sea. But professional land-based criminals hire these modern pirates to steal boats, which they then convert into "phantom ships" and resell. They pay these modern pirates lump sums and contract them on a case-by-case basis. Like the maritime muggers, pirates-for-hire rely predominantly on hijacking methods to steal ships, though for larger vessels they have been known to plant "insiders"-sailors who pretend to be legitimate sailors seeking employment on the ship in question-who later hijack the target from the inside.

Since modern pirates sail in very small groups and spend very little time together at sea, they do not exhibit any discernible organizational structure, as seventeenth- and eighteenth-century pirates clearly did. Unlike older pirates, privateers, merchantmen, or explorers, the "inand-out" character of modern pirates, coupled with the fact that crews are so small, means that they do not require rules for creating order, rationing provisions, or assigning tasks. Modern pirates do not even require captains in the usual sense. There is, of course, someone who steers the motorboat and acts as a leader among the six or so pirates; but he is not a captain in the way that eighteenth-century pirate, privateer, or merchant captains were.

Even organizational problems related to the distribution of plunder are largely absent for modern pirates. The sea muggers need to divide what they steal. But nothing structured is required since, unlike seventeenth- and eighteenth-century pirates, modern sea robbers do not sail for extended periods with growing piles of booty. Their trips are evening cruises. When they end, the pirates return to their day jobs. Modern pirates-for-hire do not even confront a distribution of booty problem to this extent. The landed thieves who employ them pay them wages. Once the pirates have taken a prize, they hand it over to their 
employer. Sadly, then, modern pirates are far less interesting from an economic or organizational point of view than their predecessors.

The institutions of seventeenth- and eighteenth-century pirates, in contrast, provide an important glimpse into the typically invisible governance mechanisms that support cooperation inside criminal organizations. My analysis of the law, economics, and organization of pirates leads to three conclusions.

First, ordinary "foot soldiers" inside criminal organizations may face a problem of leader predation similar to the problem citizens under governments face with respect to political rulers. Importantly, organized criminals' inability to rely on state-created institutions to overcome this problem does not prevent them from developing private, self-enforcing institutions for this purpose instead. "Kings were not needed to invent the pirate system of governance" (Rogozinski 2000, 184). It is unlikely that they are needed to invent systems of governance in other criminal organizations either.

Second, the institutions that constituted the pirates' system of governance-democratic checks, the separation of power, and constitutions-are remarkably similar to those governments employ to constrain ruler predation in the "legitimate world." Government does not have a monopoly on these institutions of governance any more than it has a monopoly on the ability to generate cooperation and order. The success of pirate "an-arrgh-chy" highlights both of these facts.

In the same way that merchant ship autocracy reflected an efficient institutional response to the particular economic situation that merchant ships faced, pirate organization reflected an efficient institutional response to the particular, and rather different, economic situation that pirate ships faced. The efficiency of piratical institutions, it seems, resulted at least in part from this economic difference between pirate and merchant ships, not from the former's inability to rely on government support for autocratic organization.

Finally, organized criminals are as interested in creating order among themselves as noncriminals. They, too, have an incentive to develop solutions to obstacles that otherwise prevent them from cooperating for mutual gain. The fact that they direct their cooperation at someone else's loss does not alter this. Thus, while Captain Charles Johnson described the pirates' criminal organization as "that abominable Society" $(1726-28,114)$, it is important to acknowledge that, however abominable, it was nevertheless a society.

\section{References}

Anderson, Annelise Graebner. 1979. The Business of Organized Crime: A Cosa Nostra Family. Stanford, CA: Hoover Inst. Press. 
Anderson, Terry L., Bruce L. Benson, and Thomas E. Flanagan, eds. 2006. SelfDetermination: The Other Path for Native Americans. Stanford, CA: Stanford Univ. Press.

Anderson, Terry L., and Peter J. Hill. 2004. The Not So Wild, Wild West: Property Rights on the Frontier. Stanford, CA: Stanford Univ. Press.

Anderson, Terry L., and Fred S. McChesney, eds. 2002. Property Rights: Contract, Conflict, and Law. Princeton, NJ: Princeton Univ. Press.

Arlacchi, Pino. 1986. Mafia Business: The Mafia Ethic and the Spirit of Capitalism. London: Verso.

Becker, Gary S. 1968. "Crime and Punishment: An Economic Approach." J.P.E. 76 (March/April): 169-217.

Benjamin, Daniel K., and Christopher Thornberg. 2007. "Organization and Incentives in the Age of Sail." Explorations Econ. Hist. 44 (April): 317-41.

Benson, Bruce L. 1988. "Legal Evolution in Primitive Societies." J. Inst. and Theoretical Econ. 144 (December): 772-88.

. 1989. "The Spontaneous Evolution of Commercial Law." Southern Econ. J. 55 (January): 644-61.

. 1990. The Enterprise of Law: Justice without the State. San Francisco: Pacific Res. Inst. Public Policy.

Betagh, William. 1728. A Voyage round the World . . . . London: Combes, Lacy, and Clarke.

Bucquoy, Jacobus de. 1744. Zestien Jaarige Reis nass de Inidien gedan door Jacob de Bucquoy. Haarlem: Bosch.

Burnett, John S. 2002. Dangerous Waters: Modern Piracy and Terror on the High Seas. New York: Plume.

Chang, Juin-Jen, Huei-Chung Lu, and Mingshen Chen. 2005. "Organized Crime or Individual Crime? Endogenous Size of a Criminal Organization and the Optimal Law Enforcement." Econ. Inquiry 43 (July): 661-75.

Cook, James. [1768-80] 2003. James Cook: The Journals. Edited by Philip Edwards. New York: Penguin Classics.

Cordingly, David, ed. 1996. Pirates: Terror on the High Seas, from the Caribbean to the South China Sea. Atlanta: Turner Pub.

. 2006. Under the Black Flag: The Romance and the Reality of Life among the Pirates. New York: Random House.

Dampier, William. [1697-1707] 2005. The Buccaneer Explorer: William Dampier's Voyages. Edited by Gerald Norris. Woodbridge, UK: Boydell.

Davis, Lance E., Robert E. Gallman, and Karin Gleiter. 1998. In Pursuit of Leviathan: Technology, Institutions, Productivity, and Profits in American Whaling, 18161906. Chicago: Univ. Chicago Press (for NBER).

Davis, Ralph. 1962. The Rise of the English Shipping Industry in the Seventeenth and Eighteenth Centuries. London: Macmillan.

Dick, Andrew R. 1995. "When Does Organized Crime Pay? A Transaction Cost Analysis." Internat. Rev. Law and Econ. 15 (January): 25-45.

Downing, Clement. [1737] 1924. A History of the Indian Wars. Edited by William Foster. London: Oxford Univ. Press.

Earle, Peter. 1998. Sailors: English Merchant Seamen, 1650-1775. London: Methuen.

Exquemelin, Alexander O. [1678] 2000. The Buccaneers of America. Translated by Alexis Brown. Mineola, NY: Dover.

Fiorentini, Gianluca, and Sam Peltzman, eds. 1995. The Economics of Organised Crime. Cambridge: Cambridge Univ. Press. 
Friedman, David. 1979. "Private Creation and Enforcement of Law: A Historical Case.” J. Legal Studies 8 (March): 399-415.

Furbank, Philip N., and W. R. Owens. 1988. The Canonisation of Daniel Defoe. New Haven, CT: Yale Univ. Press.

Gambetta, Diego. 1993. The Sicilian Mafia: The Business of Private Protection. Cambridge, MA: Harvard Univ. Press.

Garoupa, Nuno. 2000. "The Economics of Organized Crime and Optimal Law Enforcement." Econ. Inquiry 38 (April): 278-88.

Gifford, Adam, Jr. 1993. "The Economic Organization of 17th- through Mid 19th-Century Whaling and Shipping." J. Econ. Behavior and Organization 20 (February): 137-50.

Gosse, Philip. 1946. The History of Piracy. New York: Tudor.

Gottschalk, Jack A., and Brian P. Flanagan. 2000. Jolly Roger with an Uzi: The Rise and Threat of Modern Piracy. Annapolis, MD: U.S. Naval Inst. Press.

Guillemard, Francis H. H. 1890. The Life of Ferdinand Magellan, and the First Circumnavigation of the Globe, 1480-1521. London: Philip and Son.

Hayward, Arthur L., ed. [1735] 1874. Lives of the Most Remarkable Criminals . . . : Collected from Original Papers and Authentic Memoirs. 2 vols. London: Reeves and Turner.

Hughes, Jonathan R. T., and Louis P. Cain. 1994. American Economic History. 4th ed. New York: HarperCollins.

Huntford, Roland. 1999. The Last Place on Earth: Scott and Amundsen's Race to the South Pole. New York: Random House.

Jameson, J. Franklin, ed. 1923. Privateering and Piracy in the Colonial Period: Illustrative Documents. New York: Macmillan.

Jankowski, Martin Sanchez. 1991. Islands in the Street: Gangs and American Urban Society. Berkeley: Univ. California Press.

Jennings, William P., Jr. 1984. "A Note on the Economics of Organized Crime." Eastern Econ. J. 10 (July-September): 315-21.

Johnson, Charles. [1726-28] 1999. A General History of the Pyrates, From Their First Rise and Settlement in the Island of Providence, to the Present Time. Edited by Manuel Schonhorn. New York: Dover.

Kinkor, Kenneth J. 2001. "Black Men under the Black Flag." In Bandits at Sea: A Pirates Reader, edited by C. R. Pennell. New York: New York Univ. Press.

Konrad, Kai A., and Stergios Skaperdas. 1998. "Extortion." Economica 65 (November): 461-77.

Konstam, Angus. 2002. The History of Pirates. Guilford, CT: Lyons.

$$
\text { Osprey. }
$$

Langewiesche, William. 2004. The Outlaw Sea: A World of Freedom, Chaos, and Crime. New York: North Point.

Leeson, Peter T. 2007 a. "Efficient Anarchy." Public Choice 130 (January): 41-53. - 2007b. "Trading with Bandits." J. Law and Econ. 50 (May): 303-21.

. Forthcoming. "Social Distance and Self-Enforcing Exchange." J. Legal Studies.

Levitt, Steven D., and Sudhir Alladi Venkatesh. 2000. "An Economic Analysis of a Drug-Selling Gang's Finances.” Q.J.E. 115 (August): 755-89.

Marx, Jenifer G. 1996a. "The Brethren of the Coast." In Pirates: Terror on the High Seas, from the Caribbean to the South China Sea, edited by David Cordingly. Atlanta: Turner Pub.

— 1996b. "The Golden Age of Piracy." In Pirates: Terror on the High Seas, 
from the Caribbean to the South China Sea, edited by David Cordingly. Atlanta: Turner Pub.

_ 1996c. "The Pirate Round." In Pirates: Terror on the High Seas, from the Caribbean to the South China Sea, edited by David Cordingly. Atlanta: Turner Pub.

Morrell, Margot, and Stephanie Capparell. 2002. Shackleton's Way: Leadership Lessons from the Great Antarctic Explorer. New York: Penguin.

Morris, Richard B. 1965. Government and Labor in Early America. New York: Harper and Row.

Pigafetta, Antonio. [1525] 1994. Magellan's Voyage: A Narrative Account of the First Circumnavigation. Translated and edited by R. A. Skelton. New York: Dover.

Polo, Michele. 1995. "Internal Cohesion and Competition among Criminal Organisations." In The Economics of Organised Crime, edited by Gianluca Fiorentini and Sam Peltzman. Cambridge: Cambridge Univ. Press.

Pringle, Patrick. 1953. Jolly Roger: The Story of the Great Age of Piracy. New York: Norton.

Rankin, Hugh F. 1969. The Golden Age of Piracy. Williamsburg, VA: Colonial Williamsburg.

Rediker, Marcus. 1981. “Under the Banner of King Death': The Social World of Anglo-American Pirates, 1716 to 1726.” William and Mary Q. 38 (April): 203-27.

-1987. Between the Devil and the Deep Blue Sea: Merchant Seamen, Pirates and the Anglo-American Maritime World, 1700-1750. Cambridge: Cambridge Univ. Press.

- 2004. Villains of All Nations: Atlantic Pirates in the Golden Age. Boston: Beacon

Reuter, Peter. 1983. Disorganized Crime: The Economics of the Visible Hand. Cambridge, MA: MIT Press.

- 1987. Racketeering in Legitimate Industries: A Study in the Economics of Intimidation. Santa Monica, CA: Rand.

Ritchie, Robert C. 1986. Captain Kidd and the War against the Pirates. Cambridge, MA: Harvard Univ. Press.

Rodger, N. A. M. 1996. The Wooden World: An Anatomy of the Georgian Navy. New York: Norton.

. 2006. A Naval History of Britain. Vol. 2. The Command of the Ocean, 16491815. New York: Norton.

Rogers, Woodes. [1712] 2004. A Cruising Voyage round the World. Santa Barbara, CA: Narrative Press.

Rogozinski, Jan. 2000. Honor among Thieves: Captain Kidd, Henry Every, and the Pirate Democracy in the Indian Ocean. Mechanicsburg, PA: Stackpole Books.

Schelling, Thomas C. 1971. "What Is the Business of Organized Crime?" J. Public Law 20 (1): 71-84.

Skaperdas, Stergios. 2001. "The Political Economy of Organized Crime: Providing Protection When the State Does Not.” Econ. Governance 2 (3): 173-202.

Slush, Barnaby. 1709. The Nayy Royal: Or a Sea-Cook Turn'd Projector. London: Bragg.

Snelgrave, William. [1734] 1971. A New Account of Some Parts of Guinea and the Slave-Trade. London: Cass.

Spotswood, Alexander. 1882-85. The Official Letters of Alexander Spotswood. 2 vols. Richmond: Virginia Hist. Soc.

Stanley, Henry Edward, trans. and ed. 1874. The First Voyage round the World, by Magellan. London: Hakluyt Soc. 
Uring, Nathaniel. [1726] 1928. The Voyages and Travels of Captain Nathaniel Uring. London: Cassell.

Venkatesh, Sudhir Alladi, and Steven D. Levitt. 2000. “Are We a Family or a Business?' History and Disjuncture in the Urban American Street Gang." Theory and Society 29 (August): 427-62.

Woodard, Colin. 2007. The Republic of Pirates. New York: Harcourt. 